\title{
Abolition: A New Paradigm for Reform
}

\author{
Marina Bell
}

The catastrophic failure of the prison system in the United States has prompted a shift in criminal punishment system rhetoric and policy toward reform. Numerous programs and initiatives facilitate reentry for the hundreds of thousands of individuals coming out of prison every year, but these and other reforms remain problematic. They do little to improve the social and material conditions of those attempting to reintegrate. By failing to question the social, historical, political, and economic conditions of criminal system problems, they reproduce the oppressive social conditions that they are intended to address. This article diagnoses several major issues with conventional reform efforts in rehabilitation and reentry scholarship and praxis and argues that what is needed is not further attempts to improve these reforms but, rather, an approach that considers these problems through an abolitionist lens. An abolitionist frame, I suggest, is particularly useful in articulating suggestions for change. I apply an abolitionist analysis to an examination of reentry, illustrating how abolitionism helps to diagnose problematic reentry reforms and how an abolitionist approach to reentry can address these issues in a more effective, profound, and enduring way.

\section{INTRODUCTION}

The prison experiment in America has been a catastrophic failure. This idea has begun to gain traction in American public consciousness, as evidenced by recent reform trends in criminal punishment policies and rhetoric. Prisons exist, allegedly, to reduce crime, to create accountability, and to improve public safety. More than ample evidence demonstrates that they do none of these things and, in fact, often exacerbate the very conditions that they are supposed to address. With attention in policy, research, and onthe-ground efforts now purportedly moving toward rehabilitation and reentry in light of this evidence, the gravity of the reentry issue has become increasingly salient. As 95 percent of the prison population is currently being released across the country at a rate of over six hundred thousand individuals per year, it has become indefensible to ignore the fact that when we send people to prison, with few exceptions, they all come back (Travis 2005, xxi). In response, numerous programs and initiatives have been put into place to facilitate reentry for individuals coming out of prison. ${ }^{1}$

\footnotetext{
Marina Bell is PhD Candidate, Department of Criminology, Law and Society, University of California, Irvine, United States. Email: Marina.Bell@uci.edu.

1. A note on language: I have made some deliberate omissions and substitutions in my use of language throughout this work that are worth noting, for one because they may appear odd to the reader and deserving of some explanation but, more importantly, because of the ethical stance they entail. First, because it is my position that there is very little that the prison/punishment system does that can be called "justice," I do not call it the "criminal justice system." I instead use the term "criminal punishment system." Second, it is common throughout scholarly and other work on the subjects of prisons and the criminal punishment system to refer to those who go through that system as "offenders," "prisoners," "inmates," "parolees," and so on. I refer 
Despite these efforts, however, individuals attempting to reintegrate after release continue to face debilitating obstacles, with recidivism rates still sometimes comparable to what they were at the peak of the punitive era (Langan and Levin 2002; Durose, Cooper, and Snyder 2014; Jonson and Cullen 2015).

In this article, I diagnose several significant problems with major reform efforts in rehabilitation and reentry, and I argue that what is needed is not further attempts to improve these reforms but, rather, an approach that considers these problems through an abolitionist lens. I define abolitionism as the goal of extirpating carceral institutions and replacing them with nonpunitive ways of dealing with harm that empower, rather than oppress, marginalized people and communities. An abolitionist frame, I suggest, is particularly useful in thinking about and articulating suggestions for change and is preferable to a strictly "reformist reform" approach. ${ }^{2}$

The first part of this article looks at major reforms in reentry and rehabilitation and examines how they are irreparably problematic. I argue that their almost exclusive focus on the individual level - incarcerated individuals and those transitioning out - rather than on structural levels, greatly limits their ability to effect genuine change. Mainstream and traditional reentry and rehabilitation interventions target incarcerated and recently incarcerated individuals without questioning or critically engaging with the social, historical, political, and economic contexts that have brought about the dire conditions of criminal punishment in the United States. Although there are structural as well as individual levels of crime causation, extant solutions, by and large, do not address the former and, therefore, will never sufficiently address the problems plaguing reentry. Additionally, the structure and approach of these programs tends to create a very low standard and expectation for the quality of life for targeted populations, the outcome of this being that individuals who complete these programs remain trapped in circumstances of poverty and deprivation that tend to lead people to crime in the first place. I argue that, because of these problems, not only will these mainstream "solutions" be limited in their ability to bring about effective change but also that they can, and do, reproduce the oppressive and unjust social conditions they aim to address.

In the latter part of this article, I explore the abolitionist perspective and look at how it is uniquely useful in grappling with the issues surrounding reentry, and I describe what a truly reintegrative approach grounded in an abolitionist framework would look like. I focus on several reasons why reentry problems and the reforms intended to address them are best approached through an abolitionist frame. First, the problems

to these individuals simply as "people in prison," "people released from prison," or "incarcerated people" and "formerly incarcerated people." In line with the "person-first" literature, used by many social justice advocacy groups (Hickman 2015; La Vigne 2016; Agid et al., n.d.; Ellis, n.d.), I do this in order to illustrate my stance that they are people first and foremost because I believe it is not helpful to the causes many of us advance in taking up these subjects to understand the master status of these individuals as "inmates" or "offenders." I do this also because in my conversations with formerly incarcerated people I have come to understand that these terms have particular meanings that are distinct from one another for people who have done time. A "convict" is different from an "inmate." While perhaps these distinctions may seem to have little relevance to academics who have not been incarcerated, to the extent that I intend for my work as a scholar to create space for directly impacted people to be a part of the conversation on these subjects-scholarly and otherwise- I choose to respect these distinctions, even if I, as a person who identifies as system impacted but has never been incarcerated, cannot fully appreciate their significance.

2. This refers to Andre Gorz's (1967) distinction between "reformist reforms" and "non-reformist reforms," which I discuss in more detail further on. 
obstructing reintegration and effective interventions are rooted in deep structural inadequacies that reform alone will not address, and an abolitionist perspective necessitates attention to root causes in a way that a reformist reform approach does not. Unlike mainstream rehabilitation and reentry efforts, the abolitionist perspective is characterized by its challenge to the social, historical, political, and economic sources of criminal punishment system problems as well as by their racializing, oppressive, and exploitative impacts. As a number of legal scholars note, abolitionism also challenges traditional legal conceptions of justice, which are linked to liberal and progressive narratives of reform that ultimately serve to legitimate, strengthen, and expand carceral power and violence (Spade 2012; Akbar 2018; Rodriguez 2018; McLeod 2019).

Secondly, an abolitionist perspective allows for the possibility of thinking about alternative conceptions of responsibility, reintegration, justice, and who should be defining these terms and taking the lead on proposing and enacting solutions. It allows us to get out from under the constraints of how these concepts are understood within the framework of our current system, in which incarceration is thought of as an acceptable way to deal with social problems.

Third, some argue that the current punishment system is not broken, but is operating exactly as it is supposed to-purposefully working against the interests of marginalized groups (Karakatsanis 2019). These critics argue that, even under ideal conditions, we simply cannot expect this system to be just, fair, or humane. However, the basic moral orientation that human beings should not be kept in cages-especially in the systematically discriminatory and violent way we do this in America-is alarmingly absent from even the most well-intentioned policy conversations. For this reason, an "abolitionist ethic" brings something to the table that reformist approaches to the criminal punishment system do not (McLeod 2015, 1161).

\section{THE CURRENT LANDSCAPE OF REENTRY/REINTEGRATION}

With a state and federal prison population of 1,526,600 and an estimated 688,000 people being released across the country every year (Wagner and Sakala 2014; Kaeble and Cowhig 2016), one of the most pressing problems in this era of supposedly declining punitive policy in the United States is how to deal with individuals coming out of prison. Recently, research, policy, nonprofit, and other social sectors have put forth an amalgam of initiatives dedicated to facilitating reentry. However, with 76.6 percent of those released into society every year returning to prison within five years, over half of whom return within their first year of release, it is clear that these efforts are ineffectual or, at the very least, insufficient (Durose, Cooper, and Snyder 2014). The persistent reality is that the vast majority of those leaving prison face debilitating obstacles to integrating into society successfully; most struggle to access even the most basic resources necessary for a stable life, let alone a fulfilling one.

Current scholarship offers a range of explanations as to why people coming out of prison continue to face such impediments, despite reform efforts. Obstacles to reentry are often categorized in the literature in terms of formal and informal barriers. Formal barriers, sometimes referred to as invisible punishment or civil death, are the laws and practices that civilly disable individuals with a history of incarceration or a criminal 
record, resulting in the almost total loss of their rights and privileges as citizens. These sanctions, in conjunction with a host of other constraints at the federal and local levels, effectively strip formerly incarcerated people of most of the rights, protections, and freedoms fundamental to citizenship in the United States. This not only demotes formerly incarcerated people to an "ex-civilian" status (Braun 2013) but also makes it nearly impossible to find a home or regular employment (Mauer and Chesney-Lind 2002; Travis 2002, 2005; Travis, Crayton, and Mukamal 2009; Trimbur 2009; Schlager 2013; Morenoff and Harding 2014; Welsh and Rajah 2014). Formerly incarcerated people cannot access many jobs and professional licenses, due to legal sanctions, lack of job preparation, or employer stigmatization (La Vigne, Wolf, and Jannetta 2004; Travis 2005; Murphy et al. 2011; Schlager 2013). Other legal sanctions include voter disenfranchisement, exile for non-US citizens, and permanent interdiction from jury service. They are also prohibited from receiving most kinds of federal or government aid and social services such as welfare, unemployment, subsidized housing, food stamps, and eligibility for the Affordable Care Act (2010), the very services that are in place to lend assistance to individuals in precisely the position that formerly incarcerated people often find themselves - homeless, unemployed, impoverished, and lacking in vocational or educational skills and connections to legitimate employment opportunities (La Vigne, Wolf, and Jannetta 2004; Travis 2005; Uggen and Manza 2005; Uggen, Manza, and Thompson 2006; Cohen 2013; Schlager 2013).

Informal barriers to reentry include the direct effects of prisonization, such as longterm and sustained exposure to schools of crime and psychological trauma, in addition to weakened support networks and family ties, a lack of social, vocational, and educational skills (Maruna 2001; Travis 2005; Ross and Richards 2009), and a lack of effective services to assist individuals transitioning out of prison (Kubrin and Stewart 2006; Mears et al. 2008; Hipp, Petersilia, and Turner 2010). Stigma and negative public perceptions as a result of stereotypes, media depictions, and misinformation can also create problems for people attempting to reintegrate from prison by impacting their self-esteem. This can contribute to employers' reluctance to hire people with records, either because of fear of being held liable for problems that potential employers think they might cause or because of the stigma that paints formerly incarcerated people as untrustworthy, inept, or unreliable (Schlager 2013). Public perceptions can also "limit policymakers and professionals in their ability to implement and sustain reentry policies" (Garland, Wodahl, and Cota 2016, 14).

\section{CURRENT REENTRY/REHABILITATION EFFORTS AND THEIR SHORTCOMINGS}

Current reentry policy takes place, in its ideal form, in three stages: (1) in-prison rehabilitation and reentry preparation; (2) transitional support and services; and (3) long-term, post-release support, which is continued after the initial transition period (James 2014). Each stage utilizes programs and/or services that aim to reduce crime or recidivism, such as substance abuse treatment, cognitive behavioral therapy, and employment training or assistance. Programs match individuals to "treatment" through the administration of risk-needs assessments. These instruments evaluate a person's 
"risk" by tallying factors associated with crime or recidivism (such as antisocial attitudes, association with peers who have antisocial attitudes, and substance abuse) into a score, which is then used to place the person into a treatment option that is supposed to correspond to their specific type of risks and criminogenic needs (Andrews, Bonta, and Wormith 2006, 2011; Andrews et al. 2012).

The traditional approach fails not only in its implementation but also in its conventional framing. I identify conceptual and practical problems with the theoretical foundations of these policies and programs as well as with the research upon which they are based. These include a lack of attention to the structural issues involved in reentry, placing the entire burden on incarcerated and reentering people to change, and a very low standard for what counts as a successful case of "rehabilitation," which can result in dangerous neglect of people's material and psychological needs. The past decade has seen an increase in scholarly critiques of mainstream reforms and other kinds of "less punitive" alternatives, such as misdemeanor decriminalization (Natapoff 2015), diversion courts (McLeod 2012), and progressive prosecutors (Karakatsanis 2019). These scholars argue that such attempts to decrease reliance on incarceration can actually "aggravate existing pathologies in U.S. criminal law administration," expand the reach of the punishment apparatus, and strengthen the carceral state (McLeod 2012, 1587). I argue that reentry and rehabilitation reforms follow a similar pattern. I show how these conceptual problems in reentry and rehabilitation programs fundamentally limit the impact these efforts are able to have and actually cause these policies and programs to exacerbate the very issues that they are intended to address. By examining these problematic conceptual foundations, it becomes possible to see how current criminal punishment reform efforts reproduce social disadvantage and the oppressive social conditions that cause crime in the first place.

\section{Lack of Attention to Structural Issues}

Mainstream reentry and rehabilitation programs focus almost exclusively on incarcerated and reentering people rather than critically engaging with, or even considering, the historical, social, political, and economic conditions that have given rise to today's criminal punishment problems. Mainstream approaches attempt to address the symptoms of these problems but not their roots. This results in a number of issues that cause such reforms and programs to exacerbate the very problems they attempt to solve, which I discuss in the next subsections.

\section{Responsibilization, or Laundering Structural Problems through Individual Factors}

Geoff Ward (2015) describes what he calls the "laundering" of racial violence using legal variables. This is about how administrative crime data fail to account for the unequal, racialized, and racializing conditions and practices that produce that data, such as greater presence of police in communities of color, laws that target and criminalize people of color, and racist police culture that encourages the stop and arrest of nonwhites and discourages it for whites. These data and those who use them are 
"pretending," Ward says, "that prior arrest, detention, charging decisions, sentences ... objectively indicate deviance" (309). This creates what Ward calls "bias-laundering," where racially produced data are taken as race-neutral, objective measures of criminal behavior.

The same sort of "laundering" process takes place in reentry and rehabilitative programming in a more general way, through the use of risk-needs assessments, where structural problems such as inequality, exploitation, unequal distribution of resources, and structural racism are translated into individualized deficiencies of system-impacted people. In other words, because of the way risk is assessed-using variables such as race, employment status, and criminal history-marginalized people are personally blamed for the problems they face as a result of structural circumstances. This is a process that some critical scholars have called "responsiblization," where the responsibility to change is placed almost entirely on incarcerated or formerly incarcerated people (Gray 2009; Hannah-Moffat 2015, 2016; Currie 2013 Goddard and Myers 2017). Risk assessments predict criminality and recidivism based on individual factors rather than on structural ones. As a result, the programs and practices that are based upon risk assessment instruments are failing to address the primary sources of crime. This is evident in the nearexclusive focus on "offenders" and "parolees" as the targets of programs, policies, and services. This focus governs almost every aspect of the criminal punishment system, from sentencing and corrections to reentry. It also pervades corrections discourse, which is largely framed in terms of making changes to incarcerated people.

Most current rehabilitation and reentry programs are based upon research that has found specific factors or combinations of factors to be systematically associated with crime and recidivism. Such factors include substance abuse, employment, employability, education, housing, psychological health, pro-social values, coping skills, and so on (Maruna 2001; Travis 2005; Ross and Richards 2009; Cullen 2012). The majority of academic literature on the subjects of rehabilitation and reentry is situated within this risk-research paradigm and deals with how to expand and improve risk assessment technology (Coylewright 2004; Andrews, Bonta, and Wormith 2011; Baglivio and Jackowski 2013). Therefore, this hyper-focus on the individual is particularly evident in the evidence-based approach and its associated models and instruments. Evidencebased policies and programs were developed in response to what was seen as a need to adopt programs demonstrated by social scientists to be "effective" and have since become ubiquitous throughout the criminal system as a means for making decisions about those under its jurisdiction (Goldblatt and Lewis 1998). The risk assessment tools developed from this same body of research are used at almost every stage of the criminal punishment system (Andrews, Bonta, and Wormith 2006, 2011; Andrews et al. 2012). Risk assessment instruments distinguish between static and dynamic risk factors: static risk factors are traits of an individual that are "known" to predict crime, but considered unamenable to change, and therefore not considered in any treatment or intervention, such as a person's race or prior record; dynamic risk factors are those that are considered to be changeable, such as substance abuse or antisocial attitudes, and thus targeted for intervention (Bonta and Andrews 2007). These assessments calculate risk scores based on these factors and use them to determine the best course of treatment.

Critics of evidence-based programs and risk assessment technologies argue that individual-level interventions cannot address social- and structural-level problems. 
As they currently operate, risk assessments and evidence-based programs ignore wellestablished criminological and sociological research about the social-structural roots of crime and what causes someone to be "at risk" (Goddard and Myers 2017; Prins and Reich 2018). For instance, the notion that a person's race is not amenable to intervention holds true only within the framework of individual-level interventions. Race is only static when the role of the larger society in constructing and perpetuating race is excluded from consideration (Prins and Reich 2018). An extensive scholarly tradition of theory and research is devoted to explaining crime in social-, structural-, economic-, and community-level terms, yet the most widely used instrument throughout corrections agencies across North America takes little of it into account.

Although scholarship shows that structural factors have a greater impact on crime and recidivism than individual ones, risk assessments and current evidence-based approaches task individuals — who overwhelmingly hail from oppressed and marginalized groups-with their own "rehabilitation" (Currie 2013; Goddard and Myers 2017). There are several major issues with this approach. First, it demands that marginalized people learn to accept and tolerate the inequitable social conditions in which they find themselves and evaluates them as maladjusted and crime prone if they do not (Currie 2013; Goddard and Myers 2017). Program emphasis on personal responsibility and individual fault "teaches them to locate the sources of their problems mainly, if not entirely, in themselves" (Currie 2013, 5). Tim Goddard and Randolph Myers (2017) situate evidence-based programs and the risk paradigm in the history of coercive, racialized, and oppressive practices of the past, "aimed, disproportionately, at ... people of color and their families" (159), arguing that evidence-based programs and risk assessments "replicate earlier instances of oppressive assistance that 'help' ... people to better tolerate unconscionable social conditions" (160). Furthermore, risk assessments distinguishing between "criminogenic needs" and "non-criminogenic needs"-namely, needs that correspond to crime and needs that do not. Programs are then developed to address criminogenic needs, while others are deemed irrelevant to the rehabilitative process. In this sense, this approach robs individuals of the agency to decide for themselves what their needs are and, instead, prescribes needs for them.

Finally, scholars also criticize how the risk score is produced. What is supposed to be an objective and neutral score produced by a risk assessment tells us less about the characteristics of the person under evaluation than it does about the subjective decisions made by agents of a highly racialized punishment system and the external sociological conditions and practices within which the individual is situated, such as concentrated disadvantage and racial segregation (Beckett 2012). Goddard and Myers point out, for instance, that "number of past convictions"-one of the items that increases a risk score- -is not a fact about an individual but, rather, the product of discretionary decisions of police officers, prosecutors, judges, and parole officers about that individual and the application of criminal laws that disproportionately target people of color (Alexander 2010; Ward 2015; Butler 2015, 2017). The way these instruments have been designed, poor people of color "are positioned to earn more points than similarly delinquent middle-class counterparts, mostly for reasons entirely out of their control" (Goddard and Myers 2017, 155-56). Operating in ignorance of the power dynamics and structural circumstances that lead to this disproportionality and racial injustice within the criminal punishment system, risk assessments reproduce these 
conditions of social oppression (Beckett 2012; Goshe 2015; Rodriguez 2018) - the very conditions that land people in prison to begin with, which risk assessments have supposedly been developed to address. In this sense, risk assessments provide a specific example of this process of "laundering" because they "wash away the social processes that are risk producers in themselves ... assessment instruments ignore policies and practices of the state that are themselves criminogenic" (Goddard and Myers 2018, 38).

\section{Fixation on the Individual Level in Desistance Scholarship}

Even scholars who aim to escape the individual-level paradigm struggle to get out from under its conceptual constraints. To illustrate this, I look at several examples from desistance scholarship, which studies how individuals successfully give up a crimeinvolved lifestyle. I focus on this literature in particular because desistance scholars often describe their approach in terms of the need to look not only at the individual but also at "the interplay between individual choices and a range of wider social forces, institutional and societal practices which are beyond the control of the individual" (Farrall et al. 2011, 224). Specifically, I look at their use of language. Although desistance scholars acknowledge the impact of community- and social-level factors, they remain conceptually limited in so far as they consistently locate the struggles of the desistance process within the individual formerly incarcerated person, for instance, by calling for the need to further theorize and investigate "the creative responses adopted by ex-offenders to cope with the vagaries of the social world" and the "strategies that desisters must employ to compensate for their social position and highlight the need to adopt a broader and more nuanced definition of life success" (Healy 2013, 568). These suggestions include only instances of how the formerly incarcerated person changes to better fit the external circumstances in which they find themselves, when bringing about desistance clearly requires making additional kinds of changesspecifically, structural changes that cause them to find themselves in those conditions.

The struggle to get beyond the conceptual constraint of this hyper-focus on the individual is particularly visible when one notes the tension between these scholars' suggestions for practical approaches to handling the problem of the social and structural barriers that formerly incarcerated people face upon release and the language that is used to describe how these approaches might take place:

[D] esisters should be encouraged to imagine and believe in the possibility of a meaningful crime-free self ... and to formulate realistic strategies to achieve their life goals. ... However, such efforts must be supported by interventions and policies designed to improve social capital among offenders. (Healy 2013, 572)

It is unclear who might be doing this encouraging, supporting, or designing because Deirdre Healy (2013) describes these actions entirely in the passive voice and at no point identifies any actual individuals or entities who might bear these responsibilities or be willing to take them on. The only use of the active voice in the discussion refers to "offenders" and "desisters." 
Celeste Davis, Stephen Bahr, and Carol Ward $(2013,20)$ provide another example of this telling use of language: "The reintegration of offenders is part of a broader societal problem regarding those who are stigmatized and disenfranchised. In order to reduce crime and recidivism, they need help to gain access to opportunities such as education and training, employment, housing. And they need help in distancing themselves from criminal elements in society." They acknowledge that "the reintegration of offenders is part of a broader societal problem regarding those who are stigmatized and disenfranchised" - so far, so good (20). However, the rest of the paragraph identifies only "they" and "some" as subjects when referring to "offenders." Despite having just acknowledged that crime, reintegration, and recidivism are functions of societal problems, the suggestions for change are of little assistance in identifying who will provide this help and which individuals, entities, or institutions might be targeted to address the lack of access to legitimate opportunities for formerly incarcerated people. These examples likely reflect the researchers' own struggles with answers to these questions of "who" or "what." But the point here has been to illustrate the tension between these scholars' knowledge that these problems manifesting at the level of the individual are largely caused by broader-level sources of influence and their inability to articulate potential solutions in anything other than individual terms in ways that actually target those broader levels.

\section{Low Quality of Life Expectations and the Recidivism Standard}

Another major issue with traditional rehabilitation and reentry programs is a very low standard and expectation for the quality of life for populations who are the target of these programs. This stems from the widespread use of recidivism reduction as the standard for success for such programs and the standard for measuring the "success" of individuals who complete those programs. Many scholars and policy makers have lauded the Second Chance Act (SCA) (2007) as one of the most significant pieces of reentry legislation in recent years (Davis et al. 2013; Drawbridge et al. 2013; Schlager 2013). The SCA authorizes funding for programs and research pertaining to rehabilitation and reentry, including substance abuse treatment, drug courts, federal, state, tribal, and local reentry services, prison and jail education programs and career training, post-prison supervision and job placement, and mental health treatment (Department of Justice 2015). The SCA, as well as almost every other rehabilitation program in the United States, employs a single metric to determine success or failure (Cullen and Gendreau 2000; Cullen 2012)—namely, whether it produces an appreciable negative impact on recidivism (Department of Justice, Office of Justice Programs, n.d.). If individuals who complete the program return to prison more often than not, the program is a failure, and it will usually be defunded; if they tend to stay out of prison, it is "successful" and will continue to receive funding. By virtue of what has become common practice-employing recidivism reduction as the standard for program successa program's ability to reduce recidivism has come to be equated, in operational terms, with its ability to rehabilitate (Cullen and Gendreau 2000; Cullen 2012).

The fundamental problem with recidivism reduction as the one and only metric of program success has to do with the absence of any standards for a person's quality of life 
following release. As Vivian Nixon and colleagues (2008, 28; emphasis in original) note, traditional reentry "[assigns] limited life-capacity to the population of prisonersin-reentry," creating markedly low expectations for what a successful, fulfilling life is supposed to be for populations who are put through reentry programs. A hypothetical example can serve to illustrate this: a formerly incarcerated person living under a bridge, suffering from alcoholism and chronic illness, with no recourse to medical or substance abuse treatment, qualifies as rehabilitated, according to the current standard, as long as they have not been rearrested. A program whose graduates all found themselves in this position would be considered a successful program and would receive credit for its rehabilitative powers. Elliott Currie $(2013,5)$ describes the same problem:

[W] measure the "success" of these efforts in very minimal and essentially negative ways: they commit fewer crimes, do fewer drugs ... maybe get, at least briefly, some sort of job. And even if the job is basically exploitative and short-lived and their future options are slim and their present lives are still pinched, desperate and precarious, we still count that as all good-as evidence of programmatic success.

Even where qualitative standards exist, the goal is not for program participants to flourish. When these individuals manage to struggle by at minimum baseline standards under oppressive social conditions that led many to crime in the first place, the intervention is considered a success as long as they are tolerating those conditions without acting out in a "criminal" manner (Currie 2013; Goshe 2015; Goddard and Myers 2017). With that evidence-based stamp, such a program will usually enjoy continued funding and perhaps even be used as a model to be replicated in other institutions and other areas.

\section{AN ABOLITIONIST ALTERNATIVE TO REFORM}

The problematic assumptions and conceptual constraints discussed thus far are built into institutional attempts to address crime, public safety, rehabilitation, reentry, and justice as well as much of the research that supports them. This leaves us with the questions of what to do: how to approach improving conditions and positive outcomes for people in prison, people being released, and the communities they come from; how to address the major injustices that are produced and reproduced even through major efforts to rectify these problems; and how to build a truly just society. Many researchers are working to address these questions, and the typical approach is to investigate and propose ideas about how we might improve current reforms or devise new ones. Within legal scholarship, standard proposals for what to do in the face of these societal atrocities are equally wanting. Dylan Rodriguez (2018), Amna Akbar (2018), and Allegra McLeod (2019) discuss the limitations of legal scholarship's ideas about criminal punishment reform, the ways in which traditional legal perspectives of reform tend to uphold the status quo, and the trend in legal scholarship to conform to a "liberal narrative about law's tendency to do the right thing" (Akbar 2018, 476). Similarly, Rodriguez $(2018,1576)$ refers to the liberal-to-progressive reform narrative, which adheres to a view of law as tending toward progress and assumes that the violence, 
systemic bias, and institutional dysfunction of carceral systems are deviations and errors - "scandalous excesses" - rather than the fundamental and systemic features of those systems. It assumes that surface-level approaches such as internal auditing, shifts in law and policy, "piecemeal rearrangements of state infrastructure," and "bureaucratic invigorating" through increases in efficiency, surveillance, and control will be able to fix what is wrong with them $(1594,1596)$. This enables reforms that legitimate, reinforce, and augment the carceral state and ultimately serve to reproduce its mechanisms of violence and oppression.

A growing number of scholars and activists advance this argument that reform is not sufficient, that it is "superficial and deceptive" (Karakatsanis 2019, 851). This perspective is based on increasing evidence that much of what reformists claim is wrong with the criminal punishment system — such as high rates of recidivism, severe racial disparities, and extreme obstacles to reintegration-is in fact intrinsic to the logic of how it is intended to work and that it is inherently and purposively stacked against the interests of the poor, minorities, and marginalized groups (Davis 2003; Alexander 2010; Berger 2014; Butler 2015, 2017; Karakatsanis 2019). Even under ideal circumstances, these scholars argue, our current systems cannot be just, fair, or humane (Karakatsanis 2019). Therefore, attempts to address the current problems, which assume the systems in place for handling crime and dispensing "justice" are appropriate starting points that need only be improved, will not suffice. This is because the surface-level reforms that dominate mainstream conversations about the criminal punishment system "are co-opting a movement toward profound change by convincing the public that the 'law enforcement' system as we know it can operate in an objective, effective, and fair way based on 'the rule of law"' (851-52).

Scholars have provided different arguments for why reforms do greater harm than good: "Reform has a pacification effect. It calms the natives even when they should not be calm. 'False consciousness' is the term some theorists have used to describe the tendency of liberal reforms to 'dupe those at the bottom of the social and economic hierarchy' with promises of 'equality, fairness, and neutrality”' (Butler 2017, 197). Not only are reforms ineffective, so the argument goes, they are harmful and insidious in that they create the illusion of addressing criminal punishment system problems when in fact they reproduce the systems of inequality, racism, oppression, and injustice that they purport to address (Spade 2012; Rodriguez 2018; Karakatsanis 2019). Programs, and reform efforts in general, tend to divorce crime problems from their structural roots. They are dedicated to working within the current structure, therefore reifying it, and distracting from the notion that the structure itself is inherently sick, violent, and destructive.

Alec Karakatsanis (2019) identifies a number of common characteristics that these kinds of hollow reforms share. He argues that they operate from the assumption that individual problems in the punishment system such as recidivism or police bias are fixable with policies that only address those particular issues, without confronting deeper systemic ones such as white supremacy, economic deprivation, or lack of access to health care. They are based on the mythology that the system is fundamentally right and good and capable of achieving justice and that it is just that it has gone wrong in some areas. They do not shift power, control, and resources out of the punishment system; they keep power and control within the same institutions and actors that create and sustain the carceral state. In some cases, the proposals actually involve giving them 
greater power, such as reform projects that propose to "improve" mental health conditions in jails by constructing specialized carceral facilities to house mentally ill people or additional budget allocation to police departments for body cameras and implicit bias trainings. Their goal is to expand the punishment bureaucracy, not to shrink it, and certainly not to transfer power and resources to communities. And, finally, because these kinds of reforms maintain or augment power within the system, they make no attempt to build up institutions or sustainable infrastructure to dismantle the punishment system, such as community-based wellness.

Viviane Saleh-Hanna (2017) offers a novel and helpful framework for understanding this pattern by analyzing criminal punishment reform machinations in terms of theories developed for understanding the cycles of abusive relationships. She notes the "parallels between the tendencies of abusive men to deny the harm they inflict upon their victims and the narratives they use to legitimize their own violence with the narratives and legitimacies of the criminal justice system" (421). She looks at how these patterns of structural abuse, the cycles of repentance and empty promises of change, the victim's continued delusional acceptance of those promises, and the eventual recurrence of violence by the abuser play out throughout history and through various institutions. Her analysis contributes to a deeper understanding of the point that Butler (2017) makes in the excerpt above:

Perceptions of "calm" are a direct product of the larger cycles of structurally abusive relationships and are dangerous because they keep victims of [racial, imperialist patriarchy] invested and paradoxically believing in the ability of the system to take care of them. (Saleh-Hanna 2017, 423)

Regardless of what the criminal punishment system in the United States purports to do, or try to do, there is tremendous evidence that it operates as an apparatus for controlling and managing marginalized social groups. Put another way, prisons are functionally oppressive, racist institutions that systematically do violence to specific segments of the population (Wacquant 2001; Davis 2003; Alexander 2010). This violence goes well beyond incarcerated individuals, extending to families and communities, traversing generations, and impacting society as a whole (Ward 2012, 2015). In this sense, we can evaluate the criminal punishment system as a powerful and effective machine for upholding and reproducing certain social and political power arrangements and oppressive, unjust, and inhumane social conditions for those groups under its control.

In the conversation about solutions to criminal punishment system problems, Jeremy Travis (2005, xxii) puts forward the notion of using reentry as an orientation for theory as well as praxis-as "a prism to refract, in new ways, some age-old debates in the criminal justice field." Similarly, in McLeod's (2019) earlier-referenced treatment of diversion courts, she employs decarceration as a theoretical lens to cognitively reframe understandings of crime and punishment and help facilitate more profound systemic transformation in criminal law administration than is currently offered by this attempted alternative. In an analogous fashion to these two scholars, I propose an abolitionist framework as a theoretical orientation through which to articulate solutions and alternatives in theory, research, and praxis. The examples I have been discussing are reforms that are situated within the framework and logic of the current system and 
serve to reproduce and reinforce that system (Ben-Moshe 2013). This is evidenced by the fact that these approaches treat crime and violence as problems that can be solved by "correcting" people convicted of crimes without also looking to larger social problems. To this extent, abolitionism responds to these critiques in a way that other approaches do not. As Renée Byrd $(2016,86,88)$ observes, the abolitionist perspective is "rigorously reflective" about the connections between reform and carceral expansion and the tendency of the punishment system to co-opt critique because it "refuses to view the prison as an isolated institution" and, instead, understands it as a set of relationships that need to be entirely transformed or recreated in order to achieve anything that can actually be called justice. Abolitionism raises the question: "what if law reform was not targeted towards seeing what kinds of improvements we can make to the current system but was instead geared toward building a state governed by different logics?" (Rodriguez 2018, 479). Legal scholars who have written about the potential of an abolitionist perspective have noted its ability to provide a "cultural intervention" (Cullors 2018) and a counter-narrative to the liberal-progressive paradigm of law that upholds and legitimates state interventions through reforms that re-entrench carceral power (Akbar 2018; Rodriguez 2018). Abolitionists demand much more than surface-level reforms and instead are committed to reimagining the possibilities of law by aiming to shift power into impacted communities and "fundamentally transforming the relationship among state, market, and society" (Akbar 2018, 408). To the extent that abolitionism can be understood as "a practice, an analytical method, a present-tense visioning, a creative project, an ideological struggle," I bring an abolitionist perspective to bear on the issues of reentry I have raised here (Rodriguez 2018).

In the remaining sections of this article, I explore the abolitionist perspective and some of its implications and sketch out some basic elements of a working abolitionist theoretical framework. I describe the specific version of the abolitionist framework that I put forward and how it answers to the challenges of reentry and reintegration raised in the first half of this work. I then employ this framework to examine several examples of mainstream reentry efforts and show how this application elucidates precisely what is at issue in these approaches. I contrast these examples with a discussion of specific abolitionist approaches to reentry, demonstrating how they answer the various problems with traditional reentry. Finally, I discuss some of the challenges of an abolitionist vision, and I entertain and respond to some of these critiques.

\section{What Abolitionism Is}

The goal of abolition, as it will be discussed here, is to eliminate carceral institutions, the prison industrial complex, and the criminal punishment system as a whole, and to replace them with nonpunitive ways of addressing harm that empower, rather than disenfranchise, vulnerable populations and communities. The project of abolition is contextualized by most abolitionists as part of a longer history of struggle against colonialism, enslavement, and white supremacy_of rebellion and resistance-as a next step in that larger project (Davis 2003, 2005; Alexander 2010; Byrd 2016; Rodriguez 2018). It is a rejection of the propagated notion that the primary purpose of the criminal punishment system is public safety, understanding instead that it exists to sustain 
and serve the interest of imperialist, racial capitalism (Davis 2003, 2005; Calathes 2017; Saleh-Hanna 2017).

The term "prison industrial complex," which is employed frequently by abolitionists and now coming into wider usage, describes the deeply interconnected nature of the prison with corporations, government, the economy, global capitalism, and the media. It helps us understand the economic incentives behind prison construction and expansion, capturing the process through which incarceration is profitized and ensconced into the structure of local and global economies (Davis 2003, 2005; Sudbury 2004; Gilmore 2007). Derived from the military-industrial complex, the term highlights similarities between prisons and the military, as both "produce vast profits out of immense social destruction and [transform] public funds into private profits" (Sudbury 2004, 17). To the extent that the goal of many abolitionists is to dismantle not only prisons but also the prison-industrial complex as a whole, disrupting this symbiosis between prisons and these other major powers, institutions, and interests requires much more than the elimination of carceral institutions. It requires dismantling the institutional and social context within which prisons have become so deeply intertwined with the economy and are thought of as an acceptable way to deal with social problems. Fred Moten and Stefano Harney $(2004,114)$ describe the object of abolition as "[n]ot so much the abolition of prisons but the abolition of a society that could have prisons, that could have slavery, that could have the wage, and therefore not abolition as the elimination of anything but abolition as the founding of a new society." Thus, it also requires a radical restructuring of society and the redistribution of resources (Davis 2005), a fundamental transformation in the societal response to "crime" (Sudbury 2004; Davis 2005), and a transformation in our collective understanding of several basic concepts such as crime and justice (Knopp et al. 1976; Brown and Schept 2017; McLeod 2019), which are subjects I explore more in depth below.

\section{REFORMIST REFORM AND NON-REFORMIST REFORM}

By and large, the most common abolitionist position tends to be what Fay Honey Knopp and colleagues (1976) refer to as the attrition model — a gradual process of decarceration through the development and use of alternatives to punitive and carceral systems and institutions, which aim to eventually render these systems and institutions obsolete. In other words, the abolitionist position means "[t]o shrink the system into nonexistence" (Critical Resistance 2012). Theorizing this process usually involves drawing a distinction between "reformist reforms" and "non-reformist reforms" (Gorz 1967). Reformist reforms seek to make palliative improvements to and within the current system, while non-reformist reforms have as their end goal the eventual dismantling of that system and are understood to be individual elements or steps in a larger strategy of structural transformation: "Reformist reforms are situated in the discursive formation of the system as it is, so that any changes are made within or against this existing framework" and thus tend to predefine the scope of crime problems as criminal punishment system problems, instead of understanding them as part of a larger context (Ben-Moshe 2013, 87). The abolitionist critique of reformist reforms is that they "aim to improve forms of abuse or dysfunction in the criminal process" 
(McLeod 2019, 1616). A non-reformist reform approach, on the other hand, would understand, for instance, that efforts to eradicate poverty, predatory capitalism, militarization/war, and white supremacy are decarceration and crime-reduction strategies, because these things directly contribute to problems of crime, violence, and mass incarceration (Currie 1997, 2010; Davis 2005; Gilmore 2007; Tuck and Yang 2012; Coyle and Schept 2017). In this sense, the goal of closing prisons is only one leg of an abolitionist strategy, because an abolitionist approach to reform "entails a holistic engagement with the root causes and structural conditions associated with suffering, the interpersonal dynamics involved in violence, and the changes to broader social conditions and political economics necessary to bring about transformation" (McLeod 2019, 1616).

\section{A Working Abolitionist Framework}

The goals of the abolitionist project that I advance here involve several components, one of which is working to incrementally replace the criminal punishment apparatus with forms of conflict resolution and peacemaking through the pursuit of non-reformist reforms. This will require specific ideas about what kinds of policies and changes fall into the category of "non-reformist reform" and which ones do not. A number of abolitionist organizations and activists, such as Critical Resistance and Mariame Kaba, have put forward such criteria particularly in the form of abolitionist toolkits, and I continue that work here. Perhaps most important is the pursuit of abolition as a two-part project, described by William E.B. Du Bois (2017) and later abolitionist scholars, that is a negative process of dismantling and decarcerating and a positive process of creating new institutions for addressing the economic, social, and political conditions that had been dealt with through prisons. This highlights the necessity of emphasizing abolition as a project of building as much as, if not more than, it is one of tearing down. Working to create alternatives that render existing oppressive systems obsolete is in itself a way of resisting those impossibly large structural evils.

In line with pursuing a positive project as well as a negative one, another goal of the vision of abolition that I put forward here (which has been suggested by other abolitionist scholars and activists) is the creation of a new vocabulary, including the elimination and substitution of certain terms, such as offender, inmate, and criminal justice system (Shaylor and Chandler 2011; Hickman 2015; McLeod 2015; La Vigne 2016; Brown and Schept 2017; Agid et al., n.d.; Ellis, n.d.). This new vocabulary should also revise the meanings we currently attach to certain words, such as "justice," specify what should be considered in the category of "violence" or "harm," and determine what counts as "safety" and who counts as a "victim." Language has tremendous power to construct our thinking and worldviews and, in turn, construct the world and the ways we interact with it. One way we can begin the enormous task of attempting to dismantle these deeply embedded, powerful, oppressive systems, institutions, and practices is to undermine their legitimacy and challenge "the embeddedness of carceral logics" through the use of language that brings their duplicity and their abuse to light (Brown and Schept 2017, 444).

McLeod $(2019,1615)$, for instance, points out how resistance to the very notion of "crime" can work to "unmask[ ] the illegitimacy of much of what is subject to 
criminalization." She and Rodriguez (2018) also highlight the ways in which abolitionism challenges conventional legal conceptions of justice. Where conventional notions of justice take for granted "that the application of criminal sanctions offers meaningful redress without inquiring more deeply into what interests are actually served by such an outcome and in what the promised justice substantially consist" (McLeod 2019, 1640), abolitionist justice "is committed, by contrast, to a conception of justice that attends carefully to the actual outcomes of processes that claim to administer justice and that seeks, at the same time, to distribute resources and opportunities more equitably" (1619). Abolitionist justice is grounded in attention to experienced harm, seeks redress through accountability and repair, holds people accountable without punitiveness, and addresses material needs. But, perhaps even more importantly, it aims to address the roots of harm and violence through its goal of transforming structural conditions and power relations and of building power in impacted communities (Akbar 2018; McLeod 2019). This is just one example of how our use of language, what meanings we attach to the words we use, and what words we choose to ignore are some of the important ways that we can exercise our autonomy to reclaim our worldviews and resist these systems and structures on a daily basis.

\section{REENTRY THROUGH AN ABOLITIONIST LENS}

Here, I apply an abolitionist critique to examples of mainstream reentry programs, providing an explicit contrast between traditional and abolitionist reentry to illustrate the problems discussed earlier in the article and how we might do things differently. This also helps us understand what characteristics allow one to identify a program or approach as reformist or non-reformist and how abolitionist approaches to reentry respond to the critiques of ordinary reentry work that I have made thus far.

\section{Traditional Approaches to Reentry}

Here, I will discuss several examples of traditional, mainstream approaches to reentry in order to illustrate precisely where these kinds of programs are problematic. Among the most common are cognitive behavioral, employment, substance abuse, and "wrap around" programs that provide a combination of these services. The programs I look at here have been chosen based on the following criteria: (1) they are among the most common forms of programming; (2) they have been evaluated as "effective" or "promising" by at least one academic study; (3) they cater to adults; and (4) they are based in the United States. ${ }^{3}$ I will provide a discussion following a brief description of each program.

\section{Community and Law Enforcement Resources Together}

Community and Law Enforcement Resources Together (ComALERT) is a highly praised reentry program based in Brooklyn, New York, started in 1999 by the Kings

3. I have chosen these last two criteria for purposes of keeping consistency across comparisons. 
County District Attorney's Office and described by Erin Jacob and Bruce Western $(2007,1)$ as "among a new generation of prisoner re-entry programs around the country," providing "wraparound" transitional services such as substance abuse treatment and counseling, general educational development classes, job placement assistance, health insurance enrollment, and transitional housing to aid people recently released from prison in their transitions into Brooklyn communities. Its goal is to reduce recidivism of individuals on parole through this provision of services (National Institute of Justice 2011).

Twenty-four to forty-eight hours upon release from prison, individuals may be referred through the New York State Division of Parole. They are then reviewed by a ComALERT substance abuse counselor and given a psychological assessment. If admitted to the program, they are directed to the ComALERT Reentry Center, where they are assigned a social worker. Participants are mandated to attend weekly one-onone therapy and outpatient substance abuse treatment. ComALERT participants are also referred to the Ready, Willing, and Able (RWA) program, offering opportunities for employment, transitional housing, vocational training, financial management, lifeskills courses, and twelve-step meetings. RWA also provides opportunities for full-time employment in manual labor fields, primarily street cleaning jobs, with a portion of their earnings being deposited into a mandatory savings account. In addition, the program offers vocational training in food service, commercial driving, and pest control fields and assists participants in finding permanent employment. Participants also receive computer and literacy classes and tutoring, are offered residence at a temporary housing facility for up to one year, and are referred to outside programs if needed. Nine months into their time with RWA, clients enter a job search process stage, and once they obtain regular employment of some sort, they complete the program and are given two hundred dollars a month for five months following completion. The program administers random drug tests to participants; a positive test results in expulsion from the program.

ComALERT works with the Division of Parole to monitor participants through the three-to-six-month duration of their time in the program and inform parole officers of any violations. The program is funded through initiatives such as the Second Chance Act, has been positively evaluated for its recidivism-reducing power, and is rated as "promising" according to the National Institute of Justice's website crimesolutions. gov. Jacob and Western's (2007) evaluation found that 39.2 percent of participants were rearrested, compared to 47.6 percent of control group members. The program's "promising" rating is based on the fact that 15 percent of participants are less likely to be rearrested two years after release from prison than a comparison group, and, two years after release, only 27.8 percent of participants had been reconvicted, compared to 34.2 percent of control group members. Employment rates, they note, are almost twice as high among ComALERT graduates.

\section{MINNCOR and MINNCOR EMPLOY}

MINNCOR Industries (n.d.), the industry program run by the Minnesota Department of Corrections, describes its goal as being "to provide offenders job skills and training to support positive behavior and successful transition into the community." 
It is located in six institutions throughout the state and employs approximately thirteen hundred incarcerated people. It provides products made by incarcerated workers, such as furniture, custodial products, industrial garments, as well as services and subcontract manufacturing such as packaging, assembly, and cabinet making to government agencies, nonprofits, schools, and cities (MINNCOR Industries, n.d.). In 2006, MINNCOR began its EMPLOY program. According to the National Institute of Justice's crimesolutions.gov website and MINNCOR's own website, EMPLOY, run by the Minnesota Department of Corrections, was designed to reduce recidivism by aiding participants in securing and retaining employment following release.

EMPLOY is a voluntary program for which individuals must apply and maintain a clean disciplinary record throughout their participation. The program begins several months before release and continues for their first year out. Once accepted into the program, participants work with a "job training specialist" two to three months before release for two training sessions focused on skills assessment, resume writing, and interviewing skills. A week before their release, a "job development specialist" searches for potential jobs for the participant, reaches out to potential employers, and advocates on their behalf regarding their employability. And, after release, a "job retention specialist" meets with the participant and provides them with an employment portfolio containing the participant's own documents (resume, certifications), potential jobs, and other resources such as bus fare to aid their job search. Grant Duwe (2017) looked at recidivism and post-release employment outcomes for 464 individuals released from Minnesota prisons between 2006 and 2008. Participation in the program was found to reduce likelihood of recidivism by 32-63 percent, the likelihood of rearrest by 35 percent, the likelihood of reincarceration by 55 percent, and increase the odds of obtaining employment by 72 percent. Participants in the program were also 63 percent less likely to have their parole revoked for a technical violation.

\section{Postsecondary Correctional Education}

To look at an example of postsecondary education (PSE) rehabilitation/reentry programs, rather than choose a single program, I have instead chosen to draw from a particular report from the URBAN Institute that looks at four PSE programs in three different states (Winterfield et al. 2009). These programs offer college-level academic or vocational courses either through correspondence or face-to-face instruction. Their primary goal is to reduce recidivism rates; their secondary goal is to increase self-esteem and reduce misbehavior during incarceration. The URBAN report found, through qualitative focus group data as well as quantitative recidivism data, that the programs accomplished both of these goals (National Institute of Justice 2017).

\section{Abolitionist Critique}

The application of an abolitionist perspective brings to light a number of faults in these programs. First, these programs attempt to address problems such as substance abuse, lack of education, and difficulty with employment following release without questioning how these problems developed in the first place and without situating 
the issues in the larger social context from which they emerge, which need to be dealt with if any attempted solution is going to be lasting and effective. As Byrd (2016, 14) puts it, "[m]ainstream criminologists highlight the legal and de facto sanctions and barriers that result from a felony record, from education and employment to housing and health care. However, these barriers are rarely analyzed as a function of broader systems of inequality."

Second, and relatedly, these approaches all have in common the fact that they remain stuck in attempting to address these issues through individual-level interventions. Byrd $(2016,14)$ points this out as well: "[B]arriers to reentering society are framed as emanating from the inner life and lack of self-governance of the returning prisoner." The National Institute of Justice's website's entry on PSE programs notes that part of the justification for their existence is the fact that "[o]n average, prison inmates are less educated than the general public" (crimsolutions.gov). Thus, the idea behind providing PSE is to help people released from prison successfully reenter society by equipping them with basic skills in math, reading, and writing and increasing their odds of gainful employment by improving their academic and vocational skills (National Institute of Justice 2017). Both the National Institute of Justice and the URBAN report fail to even mention, let alone discuss, the fact that most individuals with educational deficits are poor people of color and that these populations are systematically deprived of education and many other things that reduce one's likelihood of being incarcerated.

The language from MINNCOR's website describing the mission and goals of its programs exhibits the same problem:

MINNCOR exists for the primary purpose of providing offender job skill training, meaningful employment, and teaching proper work habits-without burdening the tax payer. Correctional industries provide a means to minimize offender idleness and reduce costly disruptive behavior ... contributing to ... a safe and secure environment for both staff and offenders. ... In 2006, MINNCOR created the EMPLOY program to help releasing offenders find employment and become productive, tax-paying citizens ... [It] seeks to teach offenders to capitalize on vocational training and job skills learning while incarcerated and apply them to employment opportunities once released. (MINNCOR Industries, n.d.)

Structural inequalities such as lack of education, lack of job skills, substance abuse problems - issues that these programs purport to address-are cast here as individual deficiencies, as if "offender idleness" and "costly disruptive behavior" were actually the source of the problem. Even the medical language of interventions like ComALERT, and the "treatment" they provide, gives the impression that the individual is the appropriate target for intervention (Byrd 2016), "situating pathology and accountability entirely within the individual "offender" (Burch 2017, 358). This is not to say that there should never be programs that address individual issues, but it is also important for them to be situated within a larger context, for the "rehabilitative" process to include, perhaps, political education to help the people going through them understand the collective, social-structural circumstances of their individual difficulties (Currie 2013; Goddard and Myers 2017). 
Third, another related issue with these programs is that their evaluations and their corresponding outcome measures of "success" provide little in the way of quality of life standards for their participants. The ComALERT program's standards of success are decreased recidivism, rearrest, and reconviction. MINNCOR's standards are detailed more precisely in the Minnesota Department of Corrections's $(2018,6)$ official Strategic Plan 2018 report: in addition to recidivism reduction, they include such standards as "offenders work or are involved in programming" "offender compliance" with things like child support orders and restitution payments, "offenders complete chemical dependency programming," and other forms of treatment. The PSE evaluation is the only one that includes any discussion of outcomes relating to quality of life. The authors describe some of the effects of PSE programming as increased self-esteem and pride in their education accomplishments. However, among these, they describe another positive outcome that is particularly problematic: a new, positive attitude toward their incarceration. This invokes a larger critique often made of such programs-namely, that many reformist reform approaches merely help people to "better endure unjust social conditions" as opposed to actually addressing these conditions (Goddard and Myers 2017, 130).

Fourth, another abolitionist critique of the kinds of programs discussed here, which allows one to identify them as reformist reform approaches, has to do with the language they use. As explained above, language is a powerful tool for constructing meaning and determining how we think about the concepts we use. Some abolitionists and abolitionist organizations have zeroed in on the effects of oppressive language where the criminal punishment system is concerned because certain words and terms carry with them certain assumptions about the people and the concepts they describe (Agid et al., n.d.; Ellis, n.d.). Critical Resistances notes in their Abolitionist Toolkit: "[T]hese ... assumptions make the PIC [prison industrial complex] seem logical and necessary. They redefine people and actions in terms of the category or idea represented by the word. In this way a person becomes a criminal, and the act of the State putting someone in a cage becomes justice" (Agid et al., n.d).

For instance, the terms "criminal" and "offender" assume criminality, which legitimates the often unjust laws that lead these individuals to be labeled as such and legitimates the circumstances that have led them to be saddled with that label, while placing the blame entirely upon them. The term "inmate," as noted in the very first footnote of this article, carries with it certain connotations born of its use in carceral settingsindividuals being referred to by correctional officers as "inmate" or by their identification numbers rather than by their names. "Inmate," "prisoner," "criminal," "felon," and "offender" are all examples of terms that place people's status as lawbreakers or as incarcerated before their status as human beings and that define people by this one aspect of their identity rather than considering them as whole people (La Vigne 2016).

Another critique often made is that some of these terms depoliticize the reality of incarceration, criminalization, and the circumstances that lead to it (Hickman 2015). A fair number of social justice organizations, groups, and non-profits include some statement or discussion regarding the importance of "person-first" language for talking about people under criminal punishment system control, language that centers people's humanity rather than their criminality (Hickman 2015; La Vigne 2016; Agid et al., n.d; Ellis, n.d.; Osborne Association n.d.). The City of San Francisco's Board of 
Supervisors has even proposed an official resolution that would require words like "felon," "offender," "convict," "parolee," and "delinquent" to be substituted with terms such as "formerly incarcerated person" and "person under supervision" (Matier 2019). While there is no universal agreement about which terms ought to be used, most sources do tend to agree that "criminal" and "offender" are among the most problematic, with "inmate" and "prisoner" also being widely agreed upon as terms that should be avoided. The person-first language discussion advocates such terms as "incarcerated person," "formerly incarcerated person," "person with a criminal record," and so on (Ellis, n.d.).

A major characteristic of reformist approaches, criminal punishment interventions, and programs is their unreflective use of terms like "offender," illustrated by each of the examples described here-the programs themselves, as illustrated on their websites, in their reports, and in other literature, as well as in the reports evaluating them and the National Institute of Justice's website descriptions cataloging them. The MINNCOR website even includes a photo gallery with captions such as "MINNCOR Offender Assembling Wooden Object" and "MINNCOR Offender Working with Fabric." Here, they are not only referred to as "offenders" but also as "MINNOCOR Offenders," as if MINNCOR has some sort of ownership over them (Minncor Industries, n.d.).

Fifth, yet another problematic aspect of these kinds of interventions is their failure to incorporate the expertise and authority of currently incarcerated, formerly incarcerated, or otherwise system-impacted people in the development and delivery of these programs. An abolitionist critique of reformist reform efforts is their extensive use of experts and professionals who have never experienced what the subjects of these programs have-never lived in violent neighborhoods, experienced mistreatment at the hands of law enforcement, been addicted to drugs, been shot, been incarcerated, or been under any form of correctional supervision. "Safety," "justice," and "accountability"terms that appear frequently within carceral rhetoric-look very different from the perspective of system-impacted people compared to how they are defined by professionals, academics, and other experts. For instance, "public safety" in these contexts tends to be understood as safety for the white middle-to-upper class from "dangerous" minorities (though this is not always the case), while public safety to those who are the most vulnerable might also include safety from state-sanctioned violence, in addition to freedom from harm and freedom from street violence. "Accountability," in its most common understanding in carceral contexts, means accountability of "offenders" for the crimes they have been convicted of, as opposed to accountability of state institutions, government representatives, law enforcement, and every other structure, system, or institution that has helped produce the racist, classist conditions of oppression of contemporary society. "Justice," under the carceral paradigm, means punishment-not freedom from harm, oppression, subjugation, racism, classism, or reparations for centuries of harm and mistreatment.

A non-reformist reform would, at a minimum, center the experience and expertise of impacted individuals and communities. Among the strongest abolitionist organizations and interventions are those that are actually led and built, from the ground up, by impacted people, operate based on concepts of safety, justice, and accountability defined by those most impacted, and center the importance of equity, equal access to opportunities, equal distribution of resources, and freedom from harm for all people.

Sixth, another distinguishing feature of reformist reform efforts is that their funding source is, or is in some way linked to, the punishment system. Despite its collaboration 
with the Doe Fund and its RWA program-which does appear to honor person-first language as well as employ some of its graduates-ComALERT works with the Division of Parole and is directly run by the local district attorney's office (Doe Fund 2020). Therefore, not only is it financially linked to the punishment system, but it is also situated in it. MINNCOR is a division of the Minnesota Department of Corrections, whose funding comes directly from the revenue it generates through prison labor, while information regarding funding sources for PSE programs, including those evaluated in the URBAN report, are funded at least in part through incarcerated youth offender (IYO) block grants or other state higher education grants. The source of IYO grants is somewhat obscure; however, at least in California, these are issued through the California Board of State and Community Corrections, which is obviously part of the carceral state (Justicegrants.info, n.d.).

Seventh, another characteristic of traditional, reformist reform approaches in reentry, from the perspective of an abolitionist analysis, is that they look to the punishment system to "solve" problems that the punishment system itself creates and perpetuates. Mainstream reform efforts do not work to question the logics of the prison system but, instead, employ that very logic in its attempts to address problems within that system. Reform in these contexts is not something separate from carceral logic; rather, "[p]rison 'reform' ... constitutes, as it were, its programme” (Foucault 1995, 234). And, in this sense, they ultimately serve an even more nefarious purpose-namely, to help render and recast the prison system as legitimate and to help it become more adaptable and effective (Byrd 2016). Abolitionism understands that the carceral state is the product of "deeper sociohistorical and political-economic causes" of race- and class-related oppression and exploitation; it understands the punishment system as a central tool of social control because abolitionism is, at its root, about transforming systems of oppression and exploitation (Nixon et al. 2008, 22). It understands that an appropriate approach to transformation requires not merely making modifications to the punishment system but, rather, addressing the historical conditions that make it possible for such a system to evolve and targeting social conditions that lead to things like mass imprisonment in the first place, such as poverty, inequality, and structural racism. Mainstream reentry reform fails to critically engage these social and historical circumstances; it maintains the belief and projects to the public the idea that a solution can be found within the system itself, while "the basic premise of locking people in cages remains unquestioned" (Byrd 2016, 15). Andre Gorz (1967, 7-8), the progenitor of the reformist and non-reformist reform distinction, explains that a non-reformist reform "is one which is conceived not in terms of what is possible within the framework of a given system of administration, but in view of what should be made possible in terms of human needs and demands." In other words, the goal of improving people's lives should drive these changes.

\section{Abolitionist Reentry}

Here, I will provide a comparable discussion of abolitionist reentry programs and efforts, looking at four organizations and illustrating how their approaches respond to the major issues with traditional reentry raised in this article. 


\section{Forever on Course United in Solidarity Initiatives}

Forever on Course United in Solidarity (FOCUS) Initiatives is a nonprofit reentry effort in Marion County, Indiana, that self-identifies as abolitionist. They are a grassroots, community-based program that offers legal aid, housing, case management, medical and mental health services, education, community organizing, and employment opportunities both in house and in local businesses with which they are partnered (Focus Initiatives, n.d.). On the surface, the kinds of services they offer do not appear to differ significantly from those offered by ComALERT. However, there are several components that distinguish FOCUS. The first of these is in their ideological approach and the fundamental assumptions, values, and principles that guide their implementation. They approach reentry from a perspective "that takes into account the underlying or 'root' causes of mass incarceration," a perspective that understands the political, economic, and social forces that put people into the punishment system and determine their treatment once there. FOCUS operates from an understanding that "the prison system is designed to keep people incarcerated, not to rehabilitate them or prepare them for a successful future," and that, as a tool of race and class stratification, it is designed to uphold racial capitalism and patriarchal, white supremacist, heteronormative structures (Focus Initiatives, n.d.).

Another major difference that distinguishes FOCUS from traditional, mainstream, reformist reform approaches is that currently and formerly incarcerated people have designed and developed their program and its projects in collaboration with allies in the community. Their leadership is structured around, and driven by, the experience and expertise of currently and formerly incarcerated individuals. They explain that their plans for additional phases of the program include "aim[ing] for all coordinator positions to be held by current or former program members and for the majority of the directors of our non-profit organization to be people who have experienced incarceration" (Focus Initiatives, n.d.). Yet another distinguishing feature of FOCUS is their goals. In contrast to the goals of programs such as MINNCOR, to "hold offenders accountable" and "change offender behavior" (Minnesota Department of Corrections 2018), FOCUS articulates its goals as follows:

our goal, as an abolitionist re-entry project, is to support formerly incarcerated people and communities targeted by the criminal legal system in their efforts to determine their own futures according to their own needs and desires. We hope to help build resilient communities, and reinforce already existing communities, so that they are able to support people returning from prison, and through solidarity, overcome the oppressive forces of racial capitalism that drive mass incarceration. (Focus Initiatives, n.d.)

This set of goals reflects an understanding that individual-level obstacles that people tend to face before and after prison, such as difficulty finding meaningful, gainful employment and lack of education, are not the product of individual failures and shortcomings but, rather, structural problems requiring structural solutions, to which criminal punishment approaches contribute rather than solve. It reflects an understanding that truly addressing these problems requires looking for, and building, solutions outside the 
criminal punishment apparatus. This includes building resilient communities and strengthening solidarity to counter the oppressive forces of racial capitalism. FOCUS does this through empowering system-impacted people and communities to determine for themselves what their needs are, what "safety," "accountability," and "justice" mean to them, rather than imposing upon them from without, according to "experts" and "professionals" who have never experienced violence, exploitation, and oppression at the hands of the system. FOCUS maintains these goals with the explicit intention of "go[ing] beyond helping individuals, to changing the conditions that have produced mass incarceration" (Focus Initiatives, n.d.).

FOCUS receives funding from grassroots campaigns, soliciting donations, and developing partnerships with local like-minded organizations, such as Mutton Creek Farm, which plans to make training and employment opportunities available in sustainable agricultural fields. Finally, FOCUS distinguishes itself from reformist reform reentry approaches in terms of the standards it sets itself for measuring whether or not it has achieved these goals. Rather than recidivism reduction or "offender behavior," they explain that they "will evaluate the success of our program on the basis of its effectiveness in supporting members in developing their sense of empowerment and self-efficacy, and making progress toward their goals" (Focus Initiatives, n.d.). Byrd (2016, 93) explains that abolitionist reentry praxis "would center the knowledge of formerly imprisoned people to create and foster spaces for the development of their knowledge and leadership." A program that sets the empowerment, self-efficacy, and self-determination of currently and formerly incarcerated people as a measure of its success and addresses reentry-related problems by targeting conditions that produce mass imprisonment qualifies as abolitionist reentry praxis.

\section{Black and Pink}

Black and Pink is a national nonprofit organization whose aim is to abolish the criminal punishment system and provide support for system-impacted lesbian, gay, bisexual, transgender, queer, plus (LGBTQ+) individuals through advocacy, service provision, and organizing (Black and Pink 2019). The organization's founder was incarcerated at the time it was created in 2005, and it is comprised of currently and formerly incarcerated people and allies. Black and Pink runs a number of programs, including a prison pen pal program, a national advocacy coalition, a youth leadership institute, and two reentry programs. One of their reentry programs is Restore. Embolden. Amplify. Power (REAP), which works to strengthen community-based programming that serves the LGBTQ+ community and seeks to address reentry challenges faced by queer and transgender formerly incarcerated individuals (many of which overlap with those of reentering people who are not queer or transgender), such as "lack of quality and safe residency, medical care, employment and self-development." They describe their TRANSitions program, which works together with REAP, as "a conduit for safe housing specifically for formerly incarcerated transgender women who are particularly vulnerable" (Black and Pink 2019).

Black and Pink's approach is one that responds to the critiques of reformist reforms raised here, which is evident in the way they describe their projects and in how they 
undertake the work they do. They explain that one of their goals with TRANSitions is to "build a new vision for what reentry looks like." They do this in a number of ways: first, by situating the social problems they attempt to solve in a larger social context. In their coalition work, they aim to "approach issues of policing, punishment and criminalization through a racial, economic and reproductive justice framework." REAP's approach shows an understanding of the fact that social phenomena like crime and cycles of recidivism need to be understood in the context in which they take place. It also reflects an understanding that the punishment system is itself a major contributor to these problems. REAP "support[s] formerly incarcerated people to do direct service work and plac[ement] in leadership roles," illustrating the importance of not only incorporating the experience and expertise of people who have been through the system but also their leadership. Black and Pink does this through creating and supporting community-based programming to "create opportunities for formerly incarcerated people to create a quality of life that they dictate without barriers or ceilings" (Black and Pink 2019; emphasis added). This not only allows system-impacted people to define for themselves what their goals and needs are and what they take to be good measures of a successful life, but it also does so without placing that responsibility entirely upon them. Program emphasis on community, coalition building, and organizing demonstrates an understanding that these issues are not solved merely by targeting currently and formerly incarcerated people for intervention.

Finally, Black and Pink's commitment to incorporating the voices of incarcerated and formerly incarcerated people helps demonstrate their status as a non-reformist reform organization. For example, they conducted a national survey of incarcerated LGBTQ+ individuals entitled "Coming Out of Concrete Closets," which was designed with the collaboration of incarcerated people, not simply academics and industry professionals, and made available to incarcerated people, not confined to academic journals or professional forums. The report includes a list of currently incarcerated people's needs, developed by incarcerated individuals as opposed to being imposed upon them, as is the case with risk assessment models, where incarcerated people's needs are determined independently of their input, according to a clinical diagnostic model. Furthermore, they explain that the report is a tool for organizers, both inside and outside of prisons, "to strengthen national campaigns and grassroots efforts to alleviate the immediate suffering of prisoners and bring an end to the prison industrial complex while center[ing] the needs of LGBTQ prisoners" (Lydon et al. 2015, 3). In this sense, their work contributes to building power in local communities and does not place responsibility entirely upon impacted people, therefore differing significantly in its practices, principles, values, and ideology from mainstream reentry and rehabilitation approaches.

Black and Pink employ person-first language throughout their website, and while they do use the word "prisoner" in their report, they do so consciously and with specific justification and intent, having taken into consideration how the people they are describing would like to be referred to:

In our survey, we asked respondents what term they preferred to refer to themselves: prisoner, inmate, incarcerated person, person who is incarcerated, or other. We also left a blank space for respondents to offer their own suggestions. The majority of respondents chose "other." In the blank space, most 
respondents wrote in their name or simply, "my name." Given that there was no general agreement on terminology from respondents, we use the word "prisoner" as an identifying term for all incarcerated individuals. We intentionally use the term "prisoner" as it connects to the political reality of incarceration and aligns with the history of the Prisoner Rights Movement, of which we consider Black \& Pink to be a part. (Lydon et al. 2015, 13-14)

\section{Dignity and Power Now's Forever Rooted}

Dignity and Power Now (DPN) is a Los Angeles-based grassroots organization founded in 2012 by Black Lives Matter's cofounder Patrisse Khan-Cullors. DPN aims to fight for the dignity and power of incarcerated people, their families, and communities and to build an abolitionist movement led by Black and Brown people, "rooted in community power toward the goal of achieving transformative justice and healing justice" (Dignity and Power Now 2019a). They run activist and health and wellness programs, coalitions to halt jail construction and end law enforcement violence, and leadership institutions for people coming home from prison and system-impacted youth, all grounded in principles of abolition, healing justice, and transformative justice.

One of DPN's programs is Forever Rooted, a "leadership development series geared toward people coming home from prison" (Dignity and Power Now 2019a). Where a traditional reentry/rehabilitation program will usually prescribe some form of "evidencebased treatment" developed by professionals and applied according to the dictates of risk-needs assessments, Forever Rooted "uses listening, story-telling, and facilitation skills to amplify the leadership and empowerment of formerly incarcerated people." Not only is DPN an organization that fundamentally comprehends the sociohistorical, structural context of reentry, but their goal is not just for participants to obtain employment, stay clean, and avoid recidivism but, rather, to equip them with leadership skills to empower themselves. Reentering people, their families, and communities-under the leadership of system-impacted individuals_can "imagine and build alternatives to existing models of public safety, amplify the resilience of participants and their communities ... and broaden the movement towards prison abolition, healing justice, and transformative justice." Forever Rooted and DPN are targeting structural, in addition to individual, issues, and they look outside the punishment system to build solutions by working to strengthen communities and to create noncarceral, community-based systems of justice.

Not all of Dignity and Power Now's program explicitly target reentry, and they cannot in any traditional sense be called reentry programs; however, they directly address issues that arise in rehabilitation and reentry. For instance, DPN has a number of rapid response programs to address emergencies on the street that provide alternatives to policing, such as police de-escalation, street medics, therapists, counselors, and other practitioners and/or healers. This kind of holistic alternative approach can greatly reduce the possibility of further system contact that would land people behind bars. Additionally, DPN participates in JusticeLA, a coalition of other organizations and individuals working, quite successfully, with impacted communities to oppose the 
construction of new carceral facilities in Los Angeles. If there are fewer prisons and jails, there will be fewer people for whom reentry is a problem at all.

Addressing community trauma is another essential aspect of the work that organizations like DPN undertake. To this end, they also provide a Healing Justice Toolkit for the public, which is free on their website, to help people train themselves and others and learn how to respond to emergencies in ways that help reduce the possibility of system contact (Dignity and Power Now 2019b). They note that "as much as we need rapid response physically, [we] also need to deal with the trauma inflicted on families ... [and] on the community," thus they not only respond to urgent issues but also work to create an infrastructure of ongoing healing and safety so that communities can be self-sustaining in this respect (3). They offer community wellness services through their Building Resilience group, which provides things like acupuncture, massage, yoga, art and live performances, and children's stations in impacted communities, as well as right outside jails, to provide support for families visiting loved ones behind bars. They offer all of these services free of charge. Among their explicit goals are "address[ing] intergenerational trauma among Black and Brown Communities" and "transforming and ending systems of oppression to create a world in which people are healthy and care for each other" through collective practices of healing justice (Dignity and Power Now 2019a). This is a profoundly structural set of responses to the social issues surrounding reentry, which comprehend the true scope of these problems as requiring holistic, transformative, empowering, and noncarceral solutions.

\section{Initiate Justice}

Initiate Justice (IJ) is another organization that uses an abolitionist approach to reentry and related issues. IJ was founded in 2016 by two incarcerated individuals and describes its mission as ending mass incarceration "by activating the power of the people it directly impacts" (Initiate Justice 2020). IJ is 100 percent led by directly impacted people and works to achieve its goals by organizing inside and outside members through this specifically inside-outside strategy, prioritizing the leadership and voices of those most directly impacted. They work to provide resources for political education for those inside, train members both inside and out in policy change work and legislative processes, work in the community and behind bars to create concrete legal change, and publish reports, surveys, and media "that change the narrative about people impacted by incarceration and position impacted people as leaders in the CA criminal justice reform movements" (Initiate Justice 2020).

IJ runs an Institute of Impacted Leaders training, similar to DPN's Forever Rooted campaign, which is a twelve-week-long training program specifically for people directly impacted by the punishment system, where participants learn how to organize, advocate for themselves and incarcerated loved ones, and change state laws. The program includes an advocacy day at the California State Capitol and other hands-on work passing on leadership training to inside organizers. Some of their current legal campaigns include securing voting rights for individuals on parole, eliminating copayments for medical and dental services for incarcerated people, and expanding credit earnings for those eligible for youth and elderly parole (Initiate Justice 2020). 
IJ's approach reflects an abolitionist position insofar as it demonstrates a fundamental understanding of the structural nature of criminal punishment issues and works specifically to place directly impacted people as leaders in making change. It is also abolitionist in that it does not rely on the current punishment system. Instead, it works to build power and alternatives outside the system in communities, situating incarcerated and formerly incarcerated people as leaders, and it does not direct its change efforts merely at individuals, using insubstantial measures for what a "successful" program, or an individual's having "succeeded," means. ${ }^{4}$

\section{Lessons for Reentry from Abolition}

When the major problems with current reforms in the areas of reentry are examined through an abolitionist lens, it casts them in a different light and illuminates different solutions. We have just seen what these problems are and specifically how abolitionists approach them differently. An abolitionist framing of reentry and its related issues helps us understand that it makes no sense to try to address these issues by targeting incarcerated or reentering individuals alone because they are part of a much larger set of societal problems that conventional framing reentry does not take into consideration. If proposed solutions are to be successful in a meaningful and enduring way, they must engage problems such as the poverty and inequality endemic to capitalism and they must look outside of the punishment system. Successful solutions seek means of achieving safety, conflict resolution, mediation, accountability, and justice without reliance on intervention from the state, from police, or from prisons, understanding that state intervention often runs counter to the goals of peace and safety (Brown and Schept 2017; Rodriguez 2018). They attend to people's lived realities—-their immediate material needs - at the same time as they work toward long-term visions for social and structural change (Akbar 2018; Rodriguez 2018; McLeod 2019).

These approaches also have in common an understanding of harm-both harm perpetrated and harm experienced-as cyclical, non-binary, ${ }^{5}$ and inextricably connected to systemic inequities rather than as resulting from individual people or circumstances (Goddard and Myers 2018). This notion of harm provides an alternative picture for understanding how addressing problems of reentry and rehabilitation are not simply a matter of trying to target individuals for change. It also helps us in the work of linking crime and incarceration to the much larger-scale problems that give rise to them, such as predatory capitalism and the white supremacist foundations of America and its

4. A note on co-optation and compromise: in a discussion of alternative forms of justice, one would be remiss not to mention some of the ways that alternative practices and philosophies have become co-opted and made into part of the carceral machinery in the recent past, not only, notably, with restorative justice but also, more generally, with the fight for criminal punishment system change. Any work of advocating for the use of such systems as alternatives must plan to avoid this co-opting. For instance, Liat Ben-Moshe (2013, 89-90) highlights the fact that restorative justice "is mainly advocated by white middle class activists," while "its roots are mainly within indigenous communities worldwide. As a result, many poor communities of and communities of color see this framework as a form of colonialism." She suggests that "for restorative justice to be meaningful, it should come out of the communities it is trying to restore" (90).

5. Meaning transcending the stereotypical and overly simplistic victim/offender binary when, in fact, people are often both. 
institutions (Akbar 2018; Rodriguez 2018; McLeod 2019). The abolitionist organizations and programs discussed above also illuminate the importance of incorporating political education into the process of working with incarcerated or reentering people and communities. Elliott Currie's (2013) distinction between "transformative interventions" and "conformist interventions" helps to illustrate this issue. He describes conformist interventions as being designed with the intention of getting individuals to accept the oppressive conditions in which they find themselves and places the burden of change almost entirely upon those caught up in the system. Transformative interventions are intended to help people understand the larger social and structural context of their incarceration and the circumstances that led them there. These kinds of interventions are also intended to effect personal transformation through social and civic engagement in order to challenge those conditions, and scholars have attended to their success in doing so (Keahiolalo-Karasuda 2008; Shigematsu, D'Arcangelis, and Burch 2008; Goddard and Myers 2017).

Any interventions intended to help incarcerated and formerly incarcerated people should be designed and implemented by those who have been through the system themselves. Within the current reform paradigm, directly impacted people are rarely considered experts, or even authorities, on their own experience or the prison system with which they are more intimately familiar than almost anyone else. An abolitionist perspective highlights the importance of directly empowering impacted people and their families and communities to make their own decisions about what accountability, safety, justice, and resisting oppression means to them. The idea that some of the greatest sources of knowledge for ideas about how to transform our current system are those who have experienced it firsthand is alarmingly absent from mainstream discussions about how to address the problems we currently face. Many abolitionist organizations have been doing this since their inception, but this practice should be the rule, not the exception.

\section{CONCLUSION}

One of my goals in this article has been to demonstrate the importance of challenging the conventional conceptual and operational notions of reentry because current standards for defining reentry and rehabilitation, and what a successful program is, are unapologetically poor, and this has direct impacts on the lives of those whom these efforts are intended to help. It also impedes projects of genuine social transformation because it keeps us locked in a cycle of empty reform promises that not only do not deliver but that also further entrench the system by expanding its power in everincreasingly insidious ways. In focusing almost exclusively on incarcerated and formerly incarcerated individuals as targets for what need to be changed, the dominant conceptual framing of these issues, and of reform efforts in general, ensures that only one minor part of the problem is addressed; it also casts incarcerated and formerly incarcerated people as the main source of the problems at hand. In addition to falsely placing the entire blame and burden onto these individuals, this neglects the much larger social-structural factors that create these problems in the first place and that, if left unaddressed, will continue to produce and reproduce the inequality, oppression, and 
injustice that lead people to become incarcerated. This problematic conceptual framing of the issues impacts not only reform efforts and the research they are based on but also some of the scholarship that attempts to critique this work as well.

By looking at some of the major problems with the evidence-based and risk assessment paradigms and illustrating how reform efforts are shaped in terms of a specific kind of myopic narrative and the resulting practical consequences, I have shown that the true scope of problems such as reentry or reintegration is much wider than it is usually considered to be. I have also demonstrated how looking at these issues through an abolitionist lens brings these issues to the fore and illuminates possibilities for a paradigmatic shift in how we approach them. The deeply rooted causes of crime, recidivism, incarceration, and the racist and oppressive criminal punishment system that creates and perpetuates them have been neglected by reform projects and by much of the scholarship that undergirds them. An abolitionist agenda responds to this neglect in a way that other approaches do not. One does not find words such as decolonization and white supremacy, or discussions about the need to eradicate predatory capitalism, the military-industrial complex, and corporate oligarchy, in most of the conversations about criminal system problems currently taking place. Bringing abolitionist ideas into conversations about the failures of reform not only helps to bring these root causes to light, but it also offers concrete suggestions for alternative approaches and practices that help to empower and center the experience and expertise of those most impacted, address intergenerational trauma, alleviate immediate suffering, as well as create infrastructure for ongoing safety, health, and justice for individuals and communities through noncarceral and nonpunitive solutions.

However, it is also important to keep in mind that abolition is not a panacea. There are tensions and challenges within abolitionism and an abolitionist approach to reentry, many of which have yet to be worked out. The value commitments of abolitionist work can create difficult situations and moral questions, particularly at the intersection of theory and praxis. For instance, the abolitionist goal of not giving power to state systems in order to build self-sustaining, self-determining communities commits abolitionists to not calling the police under any circumstances, to not seeking retribution when violence occurs within the movement community, when we ourselves or our loved ones are harmed. It means taking responsibility when we have caused harm. This requires some challenging things of us, such as self-accountability and holding others accountable; it requires getting out from under the punitive ideology that sees justice as punishment rather than repair. It means not calling for the imprisonment or punishment of police officers when they murder unarmed black men because "justice" achieved through traditional legal channels only exacerbates cycles of violence and because such a response leaves the structural conditions and power relations that enabled such acts unchanged. Activists and organizers engaged in this work have attested to how difficult this work can be (Delisle et al. 2015; Kaba 2015, 2018; Cullors 2018; Dixon and Piepezna-Samarasinha 2020; Shank 2020; Thom 2020).

Another unresolved challenge for abolitionist thought and work has to do with the commitment to centering the voices and experiences of incarcerated people. What happens when these individuals take a position with which others in the organization or the community fundamentally disagree? What if they do not endorse abolitionism? 
A related issue is the tension between the radically progressive, socially conscious, inclusive culture of the abolitionist movement and the venomous prison culture that clings to many who are in the midst of transitioning from prison back into society (Trammell 2012; Martin 2018); this is an under-discussed and under-theorized subject in abolitionist work, scholarly or activist. There is also the perennial problem of what to do in response to questions about "the dangerous few" - that group of people, imagined or real-who constitute too great a threat to society to not be restrained. Many abolitionists respond that the very concept of "the dangerous few" reflects a troublesome understanding of violence, that instead of asking "what do we do with the dangerous people?" we need to ask ourselves why some acts are considered violent and others, such as dumping toxic waste or sending people to war, are not. When it comes to confronting this question on a practical level, abolitionists do not always agree. Some adhere to the principle that, if we truly address the roots of violence, as abolitionist reentry approaches would have us do, it is possible to create a world in which no one has to be segregated; others believe there will always be some percentage of people who will have to be removed from society, albeit in a non-punitive way.

In addition to confronting these tensions, there are other tasks that lie ahead if an abolitionist vision is going to continue to become a reality. First, there is the collective exercise of learning to shift the ideology, the cultural common sense around how society thinks about prisons, crime, punishment, violence, and so on. The prison industrial complex is thought of as inevitable, understandable, normal, and logical. For this reason, part of an abolitionist project must involve expanding our thinking, our imagination, and our ability to envision alternatives. Second, because we do not yet live in a world where alternative options have entirely taken the place of the punishment system, actualizing an abolitionist vision requires us to continue the hard work of building those alternatives as they are being used (Bonsu 2020). This is a messy process of trial and error, and so it requires giving ourselves and others room to make mistakes and having the wisdom to learn from them. Abolition is by its nature an unfinished vision, and the fact that these questions and challenges remain should not delay the work of actualizing abolitionist goals (Mathiesen 1974; McLeod 2015; Rodriguez 2018). The real work of resolving these issues will mostly likely not take place in academic discussions but, rather, among the people working on the ground to actualize abolitionist goals. My aim here has been to contribute to the efforts of those working to build a bridge between scholarship and activism, to provide informed blueprints for action in order to link scholarship to the on-the-ground work that truly moves this vision of change forward.

\section{REFERENCES}

Agid, Shana, Brooks Berndt, Rachel Herzing, and Ari Wohlfeiler. N.d. A World "without" Walls: The CR Abolition Organizing Toolkit. Oakland, CA: Critical Resistance.

Akbar, Amna A. 2018. "Toward a Radical Imagination of Law." New York University Law Review 93: 405-79.

Alexander, Michelle. 2010. The New Jim Crow: Mass Incarceration in the Age of Colorblindness. New York: New Press. 
Andrews, Don A., James Bonta, and J. Stephen Wormith. 2006. "The Recent Past and Near Future of Risk and/or Need Assessment." Crime EB Delinquency 52, no. 1: 7-27.

—. 2011. "The Risk-Need-Responsivity (RNR) Model: Does Adding the Good Lives Model Contribute to Effective Crime Prevention?" Criminal Justice and Behavior 38, no. 7: 735-55.

Andrews, Donald A., Lina Guzzo, Peter Raynor, Robert C. Rowe, L. Jill Rettinger, Albert Brews, and J. Stephen Wormith. 2012. "Are the Major Risk/Need Factors Predictive of Both Female and Male Reoffending? A Test with the Eight Domains of the Level of Service/Case Management Inventory." International Journal of Offender Therapy and Comparative Ccriminology 56, no. 1: $113-33$.

Baglivio, Michael T., and Katherine Jackowski. 2013. "Examining the Validity of a Juvenile Offending Risk Assessment Instrument across Gender and Race/Ethnicity." Youth Violence and Juvenile Justice 11, no. 1: 26-43.

Beckett, Katherine. 2012. "Race, Drugs, and Law Enforcement: Toward Equitable Policing." Criminology \& Public Policy 11: 641-54.

Ben-Moshe, Liat. 2013. "The Tension between Abolition and Reform." In The End of Prisons, edited by Mechthild E. Nagel and Anthony J. Nocella II, 83-92. Amsterdam: Brill Rodopi.

Berger, Dan. 2014. Captive Nation: Black Prison Organizing in the Civil Rights Era. Chapel Hill: University of North Carolina Press.

Black and Pink. 2019. "Black and Pink." https://www.blackandpink.org/.

Bonta, James, and Donald A. Andrews. 2007. "Risk-Need-Responsivity Model for Offender Assessment and Rehabilitation." Rehabilitation 6, no. 1: 1-22.

Bonsu, Janaé. 2020. "Excerpt from 'Black Queer Feminism as Praxis." In Beyond Survival: Strategies and Stories from the Transformative Justice Movement, edited by Ejeris Dixon and Leah Lakshmi Piepezna-Samarasinha, 49-54. Chico, CA: AK Press.

Braun, Michael Francis. "The Ex-Civilian: Intrapersonal, Interpersonal, and Structural Barriers to Recovery from Incarceration.” PhD diss., University of California, Irvine, 2013.

Brown, Michelle, and Judah Schept. 2017. "New Abolition, Criminology and a Critical Carceral Studies." Punishment $\mathcal{E}$ Society 19, no. 4: 440-62.

Burch, Melissa. 2017. "(Re) entry from the Bottom Up: Case Study of a Critical Approach to Assisting Women Coming Home from Prison.” Critical Criminology 25, no. 3: 357-74.

Butler, Paul. 2015. "The System Is Working the Way It Is Supposed To: The Limits of Criminal Justice Reform." Georgetown Law Journal 104: 1419-78.

—. 2017. Chokehold: Policing Black Men. New York: New Press.

Byrd, Renée M. 2016. "'Punishment's Twin': Theorizing Prisoner Reentry for a Politics of Abolition." Social Justice 43, no. 1: 1-22.

Calathes, William. 2017. "Racial Capitalism and Punishment Philosophy and Practices: What Really Stands in the Way of Prison Abolition." Contemporary Justice Review 20, no. 4: 442-55.

Cohen, Robin. K. 2013. The Affordable Care Act and Prisoners, OLR Research Report no. 2013-R0288. https://www.cga.ct.gov/2013/rpt/2013-R-0288.htm.

Coylewright, Jeremy. 2004. "New Strategies for Prisoner Rehabilitation in the American Criminal Justice System: Prisoner Facilitated Mediation." Journal of Health Care Law and Policy 7, no. 2: $395-422$.

Coyle, Michael J., and Judah Schept. 2017. "Penal Abolition and the State: Colonial, Racial and Gender Violences." Contemporary Justice Review 20, no. 4: 399-403.

Critical Resistance. 2012. What Is Abolition? Oakland, CA: Critical Resistance. http://critical resistance.org/wp-content/uploads/2012/06/What-is-Abolition.pdf.

Cullen, Francis T. 2012. "Taking Rehabilitation Seriously: Creativity, Science, and the Challenge of Offender Change." Punishment $\mathcal{E}$ Society 14, no. 1: 94-114.

Cullen, Francis T., and Paul Gendreau. 2000. "Assessing Correctional Rehabilitation: Policy, Practice, and Prospects." Criminal Justice 3: 109-75.

Cullors, P. 2018. "Abolition and Reparations: Histories of Resistance, Transformative Justice, and Accountability." Harvard Law Review 132: 1684-1728.

Currie, Elliott. 1997. "Market, Crime and Community: Toward a Mid-Range Theory of Post-Industrial Violence." Theoretical Criminology 1, no. 2: 147-72. 
—. 2010. "Plain Left Realism: An Appreciation, and Some Thoughts for the Future." Crime, Law and Social Change 54, no. 2: 111-24.

—. 2013. "Consciousness, Solidarity and Hope as Prevention and Rehabilitation." International Journal for Crime, Justice and Social Democracy 2, no. 2: 3-11.

Davis, Angela Y. 2003. Are Prisons Obsolete? New York: Seven Stories Press.

- 2005. Abolition Democracy: Beyond Empire, Prisons, and Torture. New York: Seven Stories Press.

Davis, Celeste, Stephen J. Bahr, and Carol Ward. 2013. "The Process of Offender Reintegration: Perceptions of What Helps Prisoners Reenter Society." Criminology \& Criminal Justice 13, no. 4: 446-69.

Davis, Lois M., Robert Bozick, Jennifer L. Steele, Jessica Saunders, and Jeremy NV Miles. 2013. Evaluating the Effectiveness of Correctional Education: A Meta-Analysis of Programs That Provide Education to Incarcerated Adults. Santa Monica, CA: Rand Corporation.

Department of Justice. 2015. Justice Department Announces \$53 Million in Grant Awards to Reduce Recidivism among Adults and Youth. Washington, DC: Office of Public Affairs. https://www. justice.gov/opa/pr/justice-department-announces-53-million-grant-awards-reduce-recidivismamong-adults-and-youth.

Department of Justice, Office of Justice Programs. N.d. Justice and Mental Health Collaboration Program FY 2016 Competitive Grant Announcement, Doc. 1121-0329. https://www.bja.gov/funding/ SCACoOccurring16.pdf.

Delisle, Claire, Maria Basualdo, Adina Ilea, and Andrea Hughes. 2015. "The International Conference on Penal Abolition (ICOPA): Exploring Dynamics and Controversies as observed at ICOPA 15 on Algonquin Territory." Champ pénal/Penal Field 12: n. pag. https://journals. openedition.org/champpenal/9146.

Dignity and Power Now. 2019a. Dignity and Power Now. http://dignityandpowernow.org/.

—. 2019b. Healing Justice Toolkit. http://dignityandpowernow.org/wp-content/uploads/2019/05/ Healing-Justice-Toolkit_PRINT_March-1.pdf.

Dixon, Ejeris, and Leah Lakshmi Piepezna-Samarasinha. 2020. Beyond Survival: Strategies and Stories from the Transformative Justice Movement. Chico, CA: AK Press.

Doe Fund. 2020. Ready Willing $\mathcal{E}$ Able. https://www.doe.org/about/history/.

Drawbridge, Dara C., Carlos E. Monteiro, Natasha A. Frost, M. S. Crow, and J. O. Smykla. 2013. "A Second Chance? Challenges in Implementing and Assessing Offender Reentry Initiatives." In Challenges in Implementing and Assessing Offender Reentry Initiatives, edited by Jones \& Bartlett Learning, LLC, 75-94. Burlington, MA: Jones \& Bartlett Learning.

Du Bois, William Edward Burghardt, ed. 2017. Black Reconstruction in America: Toward a History of the Part Which Black Folk Played in the Attempt to Reconstruct Democracy in America, 1860-1880. New York: Routledge.

Durose, Matthew R., Alexia D. Cooper, and Howard N. Snyder. 2014. Recidivism of Prisoners Released in 30 States in 2005: Patterns from 2005 to 2010. Washington, DC: US Department of Justice, Office of Justice Programs, Bureau of Justice Statistics.

Duwe, Grant. 2017. The Use and Impact of Correctional Programming for Inmates on Pre-and Post-Release Outcomes. Washington, DC: US Department of Justice, Office of Justice Programs, National Institute of Justice.

Ellis, Eddie. N.d. "An Open Letter to Our Friends on the Question of Language." Center for $\mathrm{Nu}$ Leadership on Urban Solutions. https://cmjcenter.org/wpcontent/uploads/2017/07/CNUSAppropriateLanguage.pdf.

Farrall, Stephen, Gilly Sharpe, Ben Hunter, and Adam Calverley. 2011. "Theorizing Structural and Individual-Level Processes in Desistance and Persistence: Outlining an Integrated Perspective." Australian and New Zealand Journal of Criminology 44, no. 2: 218-34.

Focus Initiatives. N.d. "Our Vision." Focus Reentry. https://www.focusreentry.com/our-vision-5.

Foucault, Michel. 1995. "Discipline and Punish: the Birth of the Prison. 1975." Trans. Alan Sheridan. New York: Vintage.

Garland, Brett, Eric Wodahl, and Lisa Cota. 2016. "Measuring Public Support for Prisoner Reentry Options." International Journal of Offender Therapy and Comparative Criminology 60, no. 12: 1406-24. 
Gilmore, Ruth Wilson. 2007. Golden Gulag: Prisons, Surplus, Crisis, and Opposition in Globalizing California. Vol. 21. Berkeley: University of California Press.

Goddard, Tim, and Randolph Myers. 2017. "Against Evidence-Based Oppression: Marginalized Youth and the Politics of Risk-Based Assessment and Intervention." Theoretical Criminology 21, no. 2: $151-67$.

- 2018. Youth, Community and the Struggle for Social Justice. New York: Routledge.

Goldblatt, Peter, and Chris Lewis, eds. 1998. Reducing Offending: An Assessment of Research Evidence on Ways of Dealing with Offending Behaviour. Vol. 187. London: Home Office.

Gorz, Andre. 1967. Strategy for Labor. Boston: Beacon Press.

Goshe, Sonya. 2015. "Moving beyond the Punitive Legacy: Taking Stock of Persistent Problems in Juvenile Justice." Youth Justice 15, no. 1: 42-56.

Gray, Patricia. 2009. "The Political Economy of Risk and the New Governance of Youth Crime." Punishment $\mathcal{E}$ Society 11, no. 4: 443-58.

Hannah-Moffat, Kelly. 2015. "Needle in a Haystack." Criminology and Public Policy 14: 113-20.

- 2016. "A Conceptual Kaleidoscope: Contemplating 'Dynamic Structural Risk' and an Uncoupling of Risk from Need." Psychology, Crime $\mathcal{E}$ Law 22, no. 1-2: 33-46.

Healy, Deirdre. 2013. "Changing Fate? Agency and the Desistance Process." Theoretical Criminology 17, no. 4: 557-74.

Hickman, Blair. 2015. "Inmate. Prison. Other. Discussed." The Marshall Project, April 3. https://www. themarshallproject.org/2015/04/03/inmate-prisoner-other-discussed.

Hipp, John R., Joan Petersilia, and Susan Turner. 2010. "Parolee Recidivism in California: The Effect of Neighborhood Context and Social Service Agency Characteristics." Criminology 48, no. 4: 947-79.

Initiate Justice. 2020. "Activating the Power of People Impacted by Incarceration." Initiate Justice. https://www.initiatejustice.org/.

Jacobs, Erin, and Bruce Western. 2007. "Report on the Evaluation of the ComALERT Prisoner Reentry Program." Brooklyn, NY: Kings County District Attorney.

James, Nathan. 2014. Offender Reentry: Correctional Statistics, Reintegration into the Community, and Recidivism. Washington, DC: Congressional Research Service.

Jonson, Cheryl Lero, and Francis T. Cullen. 2015. "Prisoner Reentry Programs." Crime and Justice 44, no. 1: 517-75.

Justicegrants. N.d. "Youthful Offender Block Grant (YOBG) (California)." Justicegrants.info. https:// www.justicegrants.info/GrantDetails.aspx?gid $=40111$.

Kaba, Mariame. 2015. "Prosecuting Cops Does Not Equal Justice.” Truthout, May 6. https://truthout. org/articles/prosecuting-cops-does-not-equal-justice/.

. 2018. "The Sentencing of Larry Nassar Was Not 'Transformative Justice.' Here's Why." The Appeal, February 5. https://theappeal.org/the-sentencing-of-larry-nassar-was-not-transformativejustice-here-s-why-a2ea323a6645/.

Kaeble, Danielle, and Mary Cowhig. 2016. Correctional Populations in the United States, 2016, Doc. NCJ-251211. Washington DC: US Department of Justice. https://www.bjs.gov/content/pub/ pdf/cpus16.pdf.

Karakatsanis, Alec. 2019. "The Punishment Bureaucracy: How to Think about Criminal Justice Reform." Yale Law Journal Forum 128: 848-935.

Keahiolalo-Karasuda, RaeDeen. 2008. "The Colonial Carceral and Prison Politics in Hawai'i." $\mathrm{PhD}$ diss., University of Hawai'i at Mānoa.

Knopp, Fay Honey, Barbara Boward, Mark Morris, and Morris Bartel Schnapper. 1976. Instead of Prisons: A Handbook for Abolitionists. Syracuse, NY: Prison Research Education Action Project.

Kubrin, Charis E., and Eric A. Stewart. 2006. "Predicting Who Reoffends: The Neglected Role of Neighborhood Context in Recidivism Studies." Criminology 44, no. 1: 165-97.

La Vigne, Nancy. 2016. "People First: Changing The Way We Talk about Those Touched by the Criminal Justice System." Urban Institute. https://www.urban.org/urban-wire/people-first-changingway-we-talk-about-those-touched-criminal-justice-system. 
La Vigne, Nancy G., Samuel J. Wolf, and Jesse Jannetta. 2004. Voices of Experience: Focus Group Findings on Prisoner Reentry in the State of Rhode Island. Washington, DC: Urban Institute.

Langan, Patrick A., and David J. Levin. 2002. "Recidivism of Prisoners Released in 1994." Federal Sentencing Reporter 15, no. 1: 58-65.

Lydon, Jason, Kamaria Carrington, Hana Low, Reed Miller, and Mahsa Yazdy. 2015. "Coming Out of Concrete Closets: A Report on Black \& Pink's National LGBTQ Prisoner Survey.” Black $\mathcal{E}$ Pink. https://www.blackandpink.org/coming-out-of-concrete-closets.

Martin, Liam. 2018. "Free but Still Walking the Yard': Prisonization and the Problems of Reentry." Journal of Contemporary Ethnography 47, no. 5: 671-94.

Maruna, Shadd. 2001. Making Good. Washington, DC: American Psychological Association.

Mathiesen, T. 1974. "2014." The Politics of Abolition of Revisited. New York: Routledge.

Matier, Phil. 2019. "SF Board of Supervisors Sanitizes Language of Criminal Justice System." San Francisco Chronicle. August 11. https://www.sfchronicle.com/bayarea/philmatier/article/SFBoard-of-Supervisors-sanitizes-language-of-14292255.php.

Mauer, Marc, and Meda Chesney-Lind. 2002. Invisible Punishment. New York: New Press.

McLeod, Allegra M. 2012. "Decarceration Courts: Possibilities and Perils of a Shifting Criminal Law." Georgetown Law Journal 100: 1587-1674.

_. 2015. "Prison Abolition and Grounded Justice." University of California Los Angeles Law Review 62: 1156-1239.

—. 2019. "Envisioning Abolition Democracy." Harvard Law Review 132, no. 6: 1613-49.

Mears, Daniel P., Xia Wang, Carter Hay, and William D. Bales. 2008. "Social Ecology and Recidivism: Implications for Prisoner Reentry." Criminology 46, no. 2: 301-40.

MINNCOR Industries. N.d. "Department of Corrections: Minncor Industries." MINNCOR Industries. https://minncor.com/.

Minnesota Department of Corrections. 2018. Strategic Plan 2018. St. Paul: Minnesota Department of Corrections. https://mn.gov/doc/assets/Strategic\%20Plan\%202018_final_tcm1089-324996.pdf.

Morenoff, Jeffrey D., and David J. Harding. 2014. "Incarceration, Prisoner Reentry, and Communities." Annual Review of Sociology 40: 411-29.

Moten, Fred, and Stefano Harney. 2004. "The University and the Undercommons: Seven Theses." Social Text 22, no. 2: 101-15.

Murphy, Daniel S., Brian Fuleihan, Stephen C. Richards, and Richard S. Jones. 2011. "The Electronic "Scarlet Letter": Criminal Backgrounding and a Perpetual Spoiled Identity." Journal of Offender Rehabilitation 50, no. 3: 101-18.

Natapoff, Alexandra. 2015. "Misdemeanor Decriminalization." Vanderbilt Law Review 68: 1055-1116.

National Institute of Justice. 2011. Program Profile: Community and Law Enforcement Resources Together (ComALERT). Washington, DC: Office of Justice Programs. https://www.crimesolutions.gov/ ProgramDetails.aspx? ID $=114$.

- 2017. Program Profile: Postsecondary Correctional Education (New Mexico). Washington, DC: Office of Justice Programs. https://www.crimesolutions.gov/ProgramDetails.aspx?ID = 511.

Nixon, Vivian, Patricia Ticento Clough, David Staples, Yolanda Johnson Peterkin, Patricia Zimmerman, Christina Voight, Sean Pica Clear, and Center for the Study of Women and Society at the Graduate and University Center, CUNY, New York. 2008. "Life Capacity Beyond Reentry: A Critical Examination of Racism and Prisoner Reentry Reform in the US." Race/Ethnicity: Multidisciplinary Global Contexts 2, no. 1: 21-43.

Osborne Association. N.d. "Resources for Humanizing Language." Osborne Association. http://www. osborneny.org/resources/resources-for-humanizing-language/.

Prins, Seth J., and Adam Reich. 2018. "Can We Avoid Reductionism in Risk Reduction?" Theoretical Criminology 22, no. 2: 258-78.

Rodriguez, Dylan. 2018. "Abolition as Praxis of Human Being: A Foreword." Harvard Law Review 132: 1568-74.

Ross, J. I., and S. C. Richards. 2009. Beyond Bars: Rejoining Society after Prison. New York: Penguin.

Saleh-Hanna, Viviane. 2017. "An Abolitionist Theory on Crime: Ending the Abusive Relationship with Racist-Imperialist-Patriarchy [RIP]." Contemporary Justice Review 20, no. 4: 419-41. 
Schlager, Melinda. 2013. Rethinking the Reentry Paradigm: A Blueprint for Action. Durham, NC: Carolina Academic Press.

Shank, Amanda Aguilar. 2020. "Beyond Firing." In Beyond Survival: Strategies and Stories from the Transformative Justice Movement, edited by Ejeris Dixon and Leah Lakshmi Piepzna-Samarasinha, 27-42. Chico, CA: AK Press.

Shaylor, Cassandra, and Cynthia Chandler. 2011. "Reform and Abolition: Points of Tension and Connection.” In Defending Justice: An Activist Resource Kit, 241-45. Boston: Political Resource Associates.

Shigematsu, Setsu, Gwen. D’Arcangelis, and Melissa Burch. 2008. "Prison Abolition in Practice: The L.E.A.D. Project, the Politics of Healing, and 'a New Way of Life." In Abolition Now! Ten Years of Strategy and Struggle against the Prison Industrial Complex, edited by Critical Resistance, 137-44. Oakland, CA: CR10 Publication Collective.

Spade, Dean. 2012. "The Only Way to End Racialized Gender Violence in Prisons Is to End Prisons: A Response to Russell Robinson's 'Masculinity as Prison." California Law Review 3: 184-96.

Sudbury, Julia. 2004. "A World without Prisons: Resisting Militarism, Globalized Punishment, and Empire." Social Justice 31, no. 1-2: 9-30.

Thom, Kai Cheng. 2020. "What to Do When You've Been Abusive." In Beyond Survival: Strategies and Stories from the Transformative Justice Movement, edited by Ejeris Dixon and Leah Lakshmi Piepezna-Samarasinha, 67-77. Chico, CA, AK Press.

Trammell, Rebecca. 2012. Enforcing the Convict Code: Violence and Prison Culture. Boulder, CO: Lynne Rienner Publishers.

Travis, Jeremy. 2002. "Invisible Punishment: An Instrument of Social Exclusion." In Invisible Punishment: The Collateral Consequences of Mass Imprisonment, edited by Marc Mauer and Meda Chesney-Lind, 15-36. New York: New Press.

- 2005. But They All Come Back: Facing the Challenges of Prisoner Reentry. Washington, DC: Urban Institute.

Travis, Jeremy, Anna Crayton, and Debbie A. Mukamal. 2009. "A New Era in Inmate Reentry." Corrections Today 71: $\mathrm{n}$. pag.

Trimbur, Lucia. 2009. "'Me and the Law Is Not Friends": How Former Prisoners Make Sense of Reentry." Qualitative Sociology 32, no. 3: 259-77.

Tuck, Eve, and K. Wayne Yang. 2012. "Decolonization Is Not a Metaphor." Decolonization: Indigeneity, Education $\mathcal{F}$ Society 1, no. 1: 1-40.

Uggen, Christopher, and Jeff Manza. 2005. "Disenfranchisement and the Civic Reintegration of Convicted Felons." In Civil Penalties, Social Consequences, edited by Christopher Mele and Teresa Miller, 67-84. New York: Routledge.

Uggen, Christopher, Jeff Manza, and Melissa Thompson. 2006. "Citizenship, Democracy, and the Civic Reintegration of Criminal Offenders." Annals of the American Academy of Political and Social Science 605, no. 1: 281-310.

Wacquant, Loic. 2001. "Deadly Symbiosis: When Ghetto and Prison Meet and Mesh." Punishment $\mathbb{E}$ Society 3, no. 1: 95-133.

Wagner, Peter, and Leah Sakala. 2014. "Mass Incarceration: The Whole Pie." Prison Policy Initiative 12: n. pag. https://www.prisonpolicy.org/reports/pie.html.

Ward, Geoff K. 2012. The Black Child-Savers: Racial Democracy and Juvenile Justice. Chicago: University of Chicago Press.

— 2015. "The Slow Violence of State Organized Race Crime." Theoretical Criminology 19, no. 3: 299-314.

Welsh, Megan, and Valli Rajah. 2014. "Rendering Invisible Punishments Visible: Using Institutional Ethnography in Feminist Criminology." Feminist Criminology 9, no. 4: 323-43.

Winterfield, Laura, Mark Coggeshall, Michelle Burke-Storer, Vanessa Correa, and Simon Tidd. 2009. The Effects of Postsecondary Correctional Education: "Final Report." Washington, DC: Urban Institute. 
68 LAW \& SOCIAL INQUIRY

\section{STATUTES CITED}

Affordable Care Act, 2010, 124 Stat. 119-1025.

Second Chance Act, 2007, 122 Stat. 657. 